\title{
Pleistocene ice caps on the coastal mountains of the Adriatic Sea
}

\author{
P.D. Hughes ${ }^{\text {a,* }}$, J.C. Woodward ${ }^{\text {a }}$, P.C. van Calsteren ${ }^{\text {b }}$, L.E. Thomas ${ }^{\text {b }}$, K.R. Adamson ${ }^{\text {a }}$ \\ ${ }^{a}$ Quaternary Environments and Geoarchaeology Research Group, Geography, School of Environment and Development, The University of Manchester, Manchester M13 9PL, UK \\ ${ }^{\mathrm{b}}$ Natural Environment Research Council-Open University Uranium-Series Facility, Department of Earth and Environmental Sciences, The Open University, Milton Keynes \\ MK7 6AA, UK
}

\section{A R T I C L E I N F O}

\section{Article history:}

Received 31 March 2010

Received in revised form

11 June 2010

Accepted 22 June 2010

\begin{abstract}
A B S T R A C T
Ice caps once covered large areas of Mount Orjen (1894 m), on the Adriatic coast of Montenegro/Bosnia Herzegovina/Croatia. The largest ice cap covered an area of c. $165 \mathrm{~km}^{2}$ and reached a maximum ice thickness of c. $450 \mathrm{~m}$, in some areas reaching down to $500 \mathrm{~m}$ above modern sea level. U-series dating of secondary carbonates within moraines indicates that the most extensive glaciation occurred during the Middle Pleistocene, correlating with a major phase of glaciation in Greece to the south during MIS 12 (c. 480-430 ka). Later, less extensive, glaciations are also recorded in the cirques and valleys and correlate with glaciations during MIS 6 (190-130 ka) and MIS 5d-2 (110-11.7 ka). Each phase of glaciation would have required large amounts of snow accumulation. Under modern precipitation values, which at c. $5000 \mathrm{~mm}$ are some of the highest in Europe, mean annual temperatures would need to be only c. $5-6{ }^{\circ} \mathrm{C}$ lower in order to form similar sized glaciers today. A mean annual temperature depression of $12-13^{\circ} \mathrm{C}$ would still require $>1000 \mathrm{~mm}$ of snow accumulation (water equivalent) to balance ablation, suggesting sustained moisture supply during Pleistocene cold stages. Such sustained precipitation supply during Pleistocene cold stages is likely to have been facilitated by major temperature contrasts between the European landmass and the Mediterranean Sea, which are likely to have sustained lee-side vortices to the south of the Alps, in the Gulf of Genoa and Adriatic Sea, forming weak moisture-bearing depressions which tracked across the eastern Adriatic coastal mountains. Large ice caps on the Dinaric Alps would have blocked the inland penetration of these depressions, resulting in much drier conditions in the Balkan interior, creating favourable conditions for the deposition of thick accumulations of loess. The last glaciers on Orjen formed during the Younger Dryas (12.9-11.7 ka) and confirm the influence of North Atlantic Ocean circulation on Pleistocene climate change in this part of the Mediterranean.
\end{abstract}

(c) 2010 Elsevier Ltd. All rights reserved.

\section{Introduction}

The Mediterranean mountains were glaciated on several occasions during the Pleistocene. Many mountain areas were host to cirque and valley glaciers (Cvijić, 1917; Messerli, 1967; Hughes et al., 2006a; Hughes and Woodward, 2009), although substantial ice caps formed over some massifs (e.g. Cowton et al., 2009). Whilst the former Mediterranean glaciers were smaller than the large Alpine and north European ice sheets, their relatively small size rendered them especially responsive to climate change (Hughes et al., 2006b).

The timing of glaciation in the Mediterranean mountains remained the subject of much speculation until recently, and many workers have assumed that the majority of moraines formed during the Late Pleistocene (e.g. Messerli, 1967; Boenzi and Palmentola, 1997). This has received support from results of

\footnotetext{
* Corresponding author. Tel.: +441612757876.

E-mail address: philip.hughes@manchester.ac.uk (P.D. Hughes).
}

cosmogenic dating in several areas, such as Turkey (Akçar et al., 2007; Sarıkaya et al., 2008), Kosovo (Kuhlemann et al., 2009) and Corsica (Kuhlemann et al., 2008). However, there is well-dated evidence for Middle Pleistocene glaciations in the Pindus Mountains of Greece (Woodward et al., 2004; Hughes et al., 2006c), the Italian Apennines (Kotarba et al., 2001; Giraudi et al., in press), the Pyrenees (Lewis et al., 2009) and also in the mountains of northwestern Iberia (Fernández-Mosquera et al., 2000; Vidal-Romaní and Fernández-Mosquera, 2006). In fact, Hughes and Woodward $(2008,2009)$ have noted significant differences in the timing and extent of glaciations across the Mediterranean mountains and sometimes within individual regions.

Some of the largest glaciers in the Balkans formed in Albania and Montenegro, especially in the inland mountains of Prokletije and Durmitor (Milivojević et al., 2008; Djurović, 2009) (Fig. 1). However, the lowest Pleistocene glaciers in the Balkans, and indeed southern Europe, formed in the coastal Dinaric Alps bordering the Adriatic Sea (Penck, 1900; Cvijić, 1900, 1917). In these areas, moraines are present at altitudes below $1000 \mathrm{~m}$ and in northern 


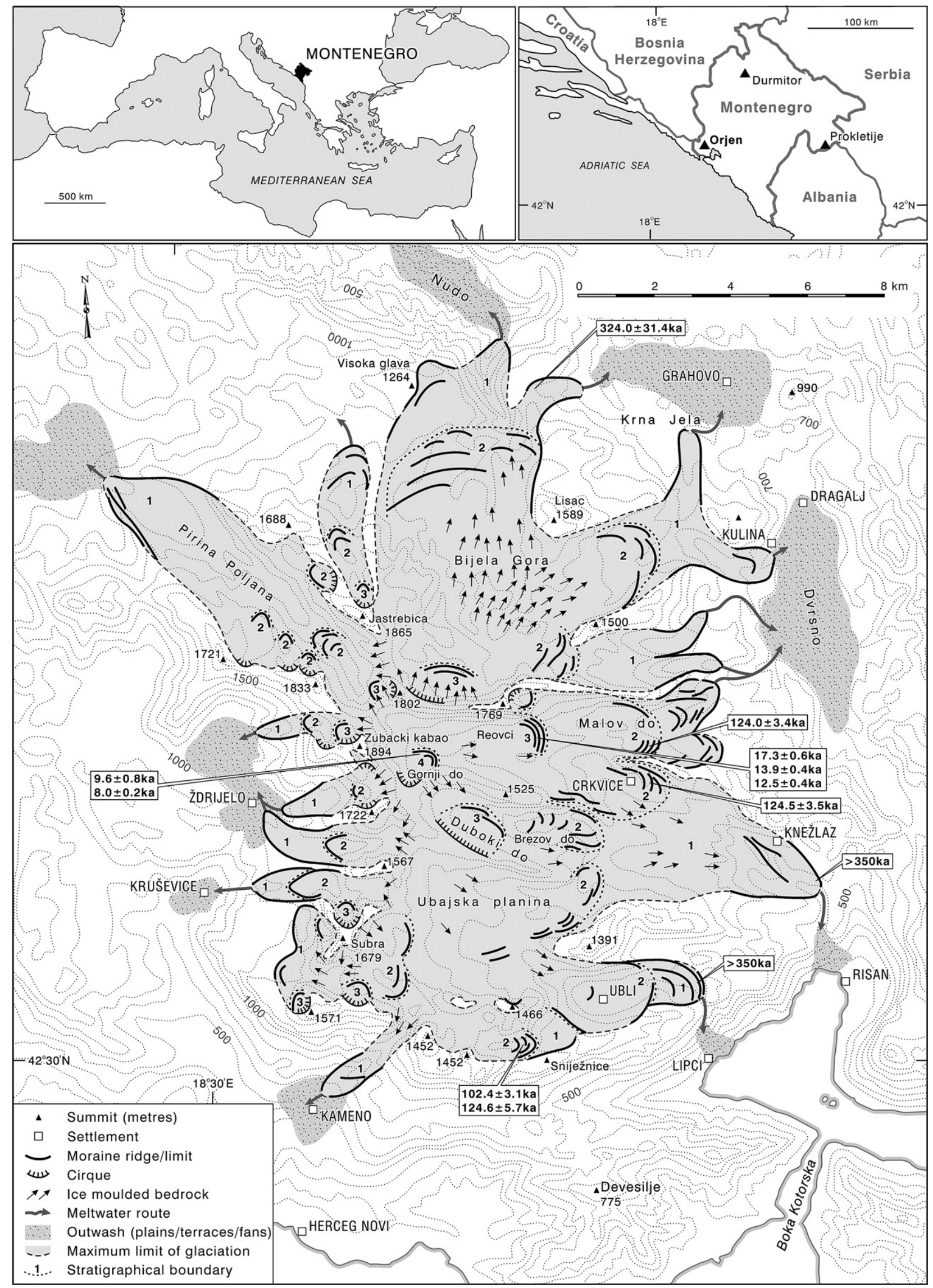

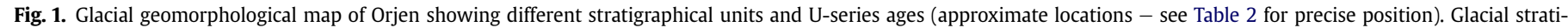
graphical units are numbered as follows: 1. Knežlaz Member; 2. Crkvice Member; 3. Reovci Member; 4. Gornji do Member. 
Dalmatia (Croatia, $44-46^{\circ} \mathrm{N}$ ) glacial deposits have even been reported at sea level (Marjanac and Marjanac, 2004). Further south, in the early years of the 20th century, Grund (1910) and Sawicki (1911) identified moraines on the western, southern and eastern slopes of Orjen $(1894 \mathrm{~m})$, which straddles the border between Croatia, Bosnia and Montenegro. Sawicki (1911) mapped moraines as low as $500 \mathrm{~m}$ overlooking the Boka Kotorska, a major embayment of the Adriatic Sea. More recently, the glacial landforms of Orjen have been noted in regional reviews of Pleistocene glaciation such as Marković et al. (2009). In addition, detailed mapping and discussion of glaciokarst on the western slopes of Orjen has been presented by Stepišnik et al. (2009). However, little progress has been made since the early 20th century as to the timing of the glaciations on Orjen, the subdivision of different glacial stratigraphical units, and the extent of glaciation in the northern region known as Bijela Gora (Fig. 1). Furthermore, the palaeoclimatic significance of glaciations in this area has not been considered.

This paper has four principal aims: 1. to present geomorphological evidence of the extent of glaciation on Orjen; 2 . to establish the number of recorded glaciations; 3 . to provide a geochronology for the glaciations, and finally; 4 . to reconstruct glacier dimensions and model the associated palaeoclimates. The final aim is of particular importance since it has implications for atmospheric circulation during Pleistocene cold stages in the wider Mediterranean region. This is especially important for understanding the environmental conditions faced by refugial populations of flora and fauna, including Palaeolithic humans, which are known to have occupied the peninsulas (Hewitt, 2000).

\section{Regional setting}

Orjen is the name given to a compact group of mountains on the borders of Croatia, Bosnia and Montenegro close to the Adriatic coast. The highest peak is Zubački kabao $(1894 \mathrm{~m})$ and 5 other summits exceed $1800 \mathrm{~m}$. The main spine of the highest peaks is situated on the western edge of the massif whilst to the east lies a series of high level valley areas, such as Reovci, Duboki do and Ubajska planina that drain into the Adriatic Sea (Fig. 1). The mountains are formed in Cretaceous limestones, which display evidence of intense karstification. The Mediterranean climate of this area shows marked seasonality, but is unusual because it receives some of the highest recorded precipitation in Europe (Table 1). At Crkvice (940 m) the average annual precipitation over the period 1931-1960 was $4926 \mathrm{~mm}$ with $8063 \mathrm{~mm}$ recorded in 1937 (Magaš, 2002). At higher elevations the precipitation totals are likely to be higher still, with average values of between at least 5000 and $6000 \mathrm{~mm}$. Furthermore, several climatologists have observed that sources of moisture such as frost, mist and fog are very significant in the Dinaric Alps and this is likely to increase the already very high precipitation values from snow and rain (Kirigin, 1967; Mileta, 2005).

\section{Field and laboratory methods}

\subsection{Geomorphological mapping}

Glacial landforms such as cirques, moraine ridges, glaciallytransported boulders and limestone pavements were mapped in the field on to $1: 50,000$ base maps. Aerial photographs were used to support the fieldwork and helped to target the field mapping. Sedimentary landform interpretation was aided by detailed logging and sediment analyses of numerous sections. Recorded parameters included clast fabric, clast shape and recording of clast surface features such as striae.

Moraines were differentiated on the basis of morphostratigraphical position (Hughes et al., 2005, 2007). The degree of soil development on moraines was also used to determine the relative age of surfaces at different morphostratigraphical positions in the valleys and cirques. Soil development was quantified using the Profile Development Index following methods described in Harden (1982) and Birkeland (1999). Soil properties were analysed on moraines at a number of strategic sites. These included valleys near Kameno, Ubli, Knežlaz, Malov do, and in the Bijela Gora (Fig. 1).

\subsection{Geochronology}

Secondary carbonates (calcite) cementing the moraines were dated using Uranium series (Woodward et al., 2004; Hughes et al., 2006c). Secondary carbonates collected in the field were cleaned and subsampled in the laboratory at the University of Manchester. Surface detritus was cleaned using a micro rotary tool with various attachments (abrasive points, micro drill). Residual dust was removed using weak hydrochloric acid (10\% conc.) then air dried. Samples were then examined using a hand lens. In the case of laminated or multilayered samples, discrete calcite laminae or crystal layers were sampled using a micro drill. In some samples where detritus inclusions were visible, whole samples were disaggregated and clean crystals were picked out using a light microscope. These were then powdered using a pestle and mortar. In each case approximately 5-20 g of powdered sample was available for U-series dating.

Chemical preparation and isotope measurements were undertaken at the UK Natural Environment Research Council Uranium Series Facility at the Open University using standard methods (cf. Edwards et al., 1987; van Calsteren and Schwieters, 1995). Samples were totally dissolved, spiked with ${ }^{236} \mathrm{U}$ and ${ }^{229} \mathrm{Th}$ tracers and the $U$ and Th fractions purified (Edwards et al., 1987). Samples were dried in separate FEP beakers and made up to approximately $10 \mathrm{ppb}$ in $3 \%$ nitric acid for isotope ratio analysis on the $\mathrm{Nu}$ Instruments MC-ICPMS. A dynamic peak-switching routine was employed measuring ${ }^{234} U /{ }^{236} U$ and ${ }^{235} U /{ }^{236} U$ (a proxy for ${ }^{238} \mathrm{U}$, assuming a ${ }^{238} \mathrm{U} /{ }^{235} \mathrm{U}$ natural ratio of 137.88 ), whilst the Thorium samples were measured using a similar dynamic peak-switching routine measuring ${ }^{230} \mathrm{Th} /{ }^{229} \mathrm{Th}$ and ${ }^{232} \mathrm{Th} /{ }^{229} \mathrm{Th}$ (Turner et al., 2001). ${ }^{232} \mathrm{Th}$ abundance was measured in order to monitor detrital Th input and consequently corrected for its presence if required. A standard-sample bracketing technique was used in order to monitor and if necessary correct for drift, and a wash programme was run between each standard and sample involving $3 \%$ nitric acid, $3 \%$ nitric acid $+0.2 \%$ HF, IPA, $2 \%$ $\mathrm{HCl}, \mathrm{MQ}$ water and back into $3 \%$ nitric acid to prevent the Th from sticking to the desolvating nebuliser (DSN). Two internal solution standards and one rock standard were used to assess external reproducibility, and total procedural blanks were run to assess blank contribution.

Table 1

Modern climate data from Crkvice (940 m) on the eastern slopes of Orjen over the period 1931-1960 (Bertić, 1987; Magaš, 2002).

\begin{tabular}{|c|c|c|c|c|c|c|c|c|c|c|c|c|c|}
\hline & $J$ & $F$ & $M$ & $A$ & $M$ & $J$ & $J$ & $A$ & $S$ & $O$ & $N$ & $D$ & $\begin{array}{l}\text { Annual } \\
\text { mean }\end{array}$ \\
\hline $\begin{array}{l}\text { Mean monthly } \\
\text { temperature }\left({ }^{\circ} \mathrm{C}\right)\end{array}$ & 0.7 & 1.7 & 3.6 & 7.7 & 12.5 & 16.3 & 19.3 & 15.4 & 15.4 & 11.0 & 6.4 & 2.5 & 9.7 \\
\hline Precipitation (mm) & 547 & 567 & 483 & 315 & 229 & 130 & 85 & 79 & 246 & 605 & 793 & 847 & 4926 \\
\hline
\end{tabular}


Table 2

U-series isotope results for secondary carbonates in moraines on Orjen, measured using TIMS. The corrected ages are based on a mean detrital ${ }^{232} \mathrm{Th} /{ }^{238} \mathrm{U}$ ratio of 2.47 , determined from detrital samples on Orjen.

\begin{tabular}{|c|c|c|c|c|c|c|c|c|c|c|c|c|c|c|}
\hline Site name & Location & $\begin{array}{l}\text { Lab } \\
\text { code }\end{array}$ & ${ }^{238} \mathrm{U} \mathrm{ppm}$ & $\left({ }^{234} U /{ }^{238} U\right)$ & ${ }^{234} \mathrm{U} \mathrm{ppb}$ & ${ }^{230} \mathrm{Th} \mathrm{ppb}$ & ${ }^{232} \mathrm{Th} \mathrm{ppb}$ & $\left({ }^{230} \mathrm{Th} /{ }^{232} \mathrm{Th}\right)$ & $\left({ }^{230} \mathrm{Th} /{ }^{234} \mathrm{U}\right)$ & $\left({ }^{234} U /{ }^{238} U\right)$ & $\begin{array}{l}\text { Uncorrected } \\
\text { age (years) - } \\
\text { error at } 2 \sigma\end{array}$ & $\begin{array}{l}\% \text { err } \\
2 \sigma\end{array}$ & $\begin{array}{l}\text { Corrected } \\
\text { age (years) }\end{array}$ & $\begin{array}{l}\% \text { err } \\
2 \sigma\end{array}$ \\
\hline Crkvice & $\begin{array}{l}42.5601 \mathrm{~N} \\
18.6314 \mathrm{E}\end{array}$ & M1 & $\begin{array}{l}0.052170 \\
\pm 0.000076\end{array}$ & $\begin{array}{l}1.630207 \\
\pm 0.005024\end{array}$ & $\begin{array}{l}0.004589 \\
\pm 0.000014\end{array}$ & $\begin{array}{l}0.001006 \\
\pm 0.000008\end{array}$ & $\begin{array}{c}4.874718 \\
\pm 0.881183\end{array}$ & $39.1 \pm 1.6$ & $\begin{array}{l}0.722239 \\
\pm 0.006085\end{array}$ & $\begin{array}{l}1.630207 \\
\pm 0.005024\end{array}$ & $\begin{array}{l}124,511 \\
\pm 3475\end{array}$ & 2.8 & $\begin{array}{l}122,250 \\
\pm 4877\end{array}$ & 4.0 \\
\hline Sniježnice & $\begin{array}{l}42.4955 \mathrm{~N} \\
18.5956 \mathrm{E}\end{array}$ & M2 & $\begin{array}{l}0.045785 \\
\pm 0.000064\end{array}$ & $\begin{array}{l}0.960872 \\
\pm 0.003278\end{array}$ & $\begin{array}{l}0.002374 \\
\pm 0.000008\end{array}$ & $\begin{array}{l}0.000436 \\
\pm 0.000004\end{array}$ & $\begin{array}{c}3.811209 \\
\pm 0.688936\end{array}$ & $22.2 \pm 0.9$ & $\begin{array}{l}0.605246 \\
\pm 0.005817\end{array}$ & $\begin{array}{l}0.960872 \\
\pm 0.003278\end{array}$ & $\begin{array}{l}102,421 \\
\pm 3143\end{array}$ & 3.1 & $\begin{array}{l}98,365 \\
\pm 4273\end{array}$ & 4.3 \\
\hline Reovci & $\begin{array}{l}42.5672 \mathrm{~N} \\
18.5889 \mathrm{E}\end{array}$ & M7 & $\begin{array}{l}0.138969 \\
\pm 0.000203\end{array}$ & $\begin{array}{l}1.032174 \\
\pm 0.002976\end{array}$ & $\begin{array}{l}0.007740 \\
\pm 0.000021\end{array}$ & $\begin{array}{l}0.000288 \\
\pm 0.000003\end{array}$ & $\begin{array}{c}1.075073 \\
\pm 0.194336\end{array}$ & $52.9 \pm 2.2$ & $\begin{array}{l}0.122636 \\
\pm 0.001085\end{array}$ & $\begin{array}{l}1.032174 \\
\pm 0.002976\end{array}$ & $\begin{array}{l}14,277 \\
\pm 268\end{array}$ & 1.9 & $\begin{array}{l}13,937 \\
\pm 370\end{array}$ & 2.7 \\
\hline Reovci & $\begin{array}{l}42.5672 \mathrm{~N} \\
18.5889 \mathrm{E}\end{array}$ & M8 & $\begin{array}{l}0.162540 \\
\pm 0.000277\end{array}$ & $\begin{array}{l}1.016071 \\
\pm 0.002859\end{array}$ & $\begin{array}{l}0.008912 \\
\pm 0.000023\end{array}$ & $\begin{array}{l}0.000298 \\
\pm 0.000003\end{array}$ & $\begin{array}{c}0.989356 \\
\pm 0.178846\end{array}$ & $58.9 \pm 2.5$ & $\begin{array}{l}0.110362 \\
\pm 0.001120\end{array}$ & $\begin{array}{l}1.016071 \\
\pm 0.002859\end{array}$ & $\begin{array}{l}12,766 \\
\pm 274\end{array}$ & 2.1 & $\begin{array}{l}12,494 \\
\pm 379\end{array}$ & 3.0 \\
\hline Bijela Gora & $\begin{array}{l}42.6497 \mathrm{~N} \\
18.5946 \mathrm{E}\end{array}$ & M10 & $\begin{array}{l}0.076709 \\
\pm 0.000122\end{array}$ & $\begin{array}{l}1.065400 \\
\pm 0.004937\end{array}$ & $\begin{array}{l}0.004410 \\
\pm 0.000020\end{array}$ & $\begin{array}{l}0.001295 \\
\pm 0.000012\end{array}$ & $\begin{array}{l}27.020854 \\
\pm 4.884446\end{array}$ & $9.0 \pm 0.4$ & $\begin{array}{l}0.967713 \\
\pm 0.008947\end{array}$ & $\begin{array}{l}1.065400 \\
\pm 0.004937\end{array}$ & $\begin{array}{l}324,025 \\
\pm 31,448\end{array}$ & 9.2 & $\begin{array}{l}309,309 \\
\pm 42,429\end{array}$ & 12.7 \\
\hline Gornji do & $\begin{array}{l}42.5652 \mathrm{~N} \\
18.5602 \mathrm{E}\end{array}$ & M15 & $\begin{array}{l}0.204074 \\
\pm 0.000454\end{array}$ & $\begin{array}{l}1.029741 \\
\pm 0.004616\end{array}$ & $\begin{array}{l}0.011340 \\
\pm 0.000046\end{array}$ & $\begin{array}{l}0.000289 \\
\pm 0.000012\end{array}$ & $\begin{array}{c}1.161971 \\
\pm 0.210045\end{array}$ & $50.0 \pm 3.7$ & $\begin{array}{l}0.083987 \\
\pm 0.003519\end{array}$ & $\begin{array}{l}1.029742 \\
\pm 0.004617\end{array}$ & $\begin{array}{l}9575 \\
\pm 839\end{array}$ & 8.7 & $\begin{array}{l}9325 \\
\pm 1156\end{array}$ & 12.4 \\
\hline Malov do & $\begin{array}{l}42.5689 \mathrm{~N} \\
18.6366 \mathrm{E}\end{array}$ & M16 & $\begin{array}{l}0.104096 \\
\pm 0.000230\end{array}$ & $\begin{array}{l}1.012738 \\
\pm 0.004901\end{array}$ & $\begin{array}{l}0.005689 \\
\pm 0.000025\end{array}$ & $\begin{array}{l}0.001174 \\
\pm 0.000010\end{array}$ & $\begin{array}{c}2.021942 \\
\pm 0.365498\end{array}$ & $108.8 \pm 4.4$ & $\begin{array}{l}0.680222 \\
\pm 0.005560\end{array}$ & $\begin{array}{l}1.012738 \\
\pm 0.004901\end{array}$ & $\begin{array}{l}124,036 \\
\pm 3434\end{array}$ & 2.8 & $\begin{array}{l}123168 \\
\pm 4835\end{array}$ & 3.9 \\
\hline Knežlaz & $\begin{array}{l}42.5373 \mathrm{~N} \\
18.6857 \mathrm{E}\end{array}$ & M18 & $\begin{array}{l}0.068301 \\
\pm 0.000105\end{array}$ & $\begin{array}{l}1.060041 \\
\pm 0.003820\end{array}$ & $\begin{array}{l}0.003907 \\
\pm 0.000014\end{array}$ & $\begin{array}{l}0.001236 \\
\pm 0.000010\end{array}$ & $\begin{array}{l}12.578129 \\
\pm 2.273694\end{array}$ & $18.5 \pm 0.8$ & $\begin{array}{l}1.043257 \\
\pm 0.008477\end{array}$ & $\begin{array}{l}1.060041 \\
\pm 0.003821\end{array}$ & $>350,000$ & & $>350,000$ & \\
\hline Sniježnice & $\begin{array}{l}42.4955 \mathrm{~N} \\
18.5956 \mathrm{E}\end{array}$ & M19 & $\begin{array}{l}0.037485 \\
\pm 0.000058\end{array}$ & $\begin{array}{l}1.034095 \\
\pm 0.004401\end{array}$ & $\begin{array}{l}0.002092 \\
\pm 0.000009\end{array}$ & $\begin{array}{l}0.000486 \\
\pm 0.000004\end{array}$ & $\begin{array}{l}23.880005 \\
\pm 4.316690\end{array}$ & $3.8 \pm 0.2$ & $\begin{array}{l}0.765809 \\
\pm 0.006271\end{array}$ & $\begin{array}{l}1.034095 \\
\pm 0.004401\end{array}$ & $\begin{array}{l}156,266 \\
\pm 5130\end{array}$ & 3.3 & $\begin{array}{l}124583 \\
\pm-5651\end{array}$ & 4.5 \\
\hline Gornji do & $\begin{array}{l}42.5642 \mathrm{~N} \\
18.5613 \mathrm{E}\end{array}$ & M21 & $\begin{array}{l}0.050466 \\
\pm 0.000072\end{array}$ & $\begin{array}{l}1.227628 \\
\pm 0.003520\end{array}$ & $\begin{array}{l}0.003343 \\
\pm 0.000009\end{array}$ & $\begin{array}{l}0.000104 \\
\pm 0.000001\end{array}$ & $\begin{array}{c}5.065957 \\
\pm 0.915752\end{array}$ & $4.2 \pm 0.2$ & $\begin{array}{l}0.102530 \\
\pm 0.000916\end{array}$ & $\begin{array}{l}1.227628 \\
\pm 0.003520\end{array}$ & $\begin{array}{l}11,774 \\
\pm 221\end{array}$ & 1.9 & $\begin{array}{l}8021 \\
\pm 214\end{array}$ & 2.7 \\
\hline Reovci & $\begin{array}{l}42.5693 \mathrm{~N} \\
18.5861 \mathrm{E}\end{array}$ & M27 & $\begin{array}{l}0.144320 \\
\pm 0.000314\end{array}$ & $\begin{array}{l}1.009269 \\
\pm 0.003457\end{array}$ & $\begin{array}{l}0.007860 \\
\pm 0.000023\end{array}$ & $\begin{array}{l}0.000361 \\
\pm 0.000004\end{array}$ & $\begin{array}{c}1.860579 \\
\pm 0.336362\end{array}$ & $41.1 \pm 1.8$ & $\begin{array}{l}0.151451 \\
\pm 0.001604\end{array}$ & $\begin{array}{l}1.009269 \\
\pm 0.003457\end{array}$ & $\begin{array}{l}17,929 \\
\pm 410\end{array}$ & 2.3 & $\begin{array}{l}17,348 \\
\pm 561\end{array}$ & 3.2 \\
\hline Ubli & $\begin{array}{l}42.5162 \mathrm{~N} \\
18.6378 \mathrm{E}\end{array}$ & M29 & $\begin{array}{l}0.505472 \\
\pm 0.001138\end{array}$ & $\begin{array}{l}1.017905 \\
\pm 0.003469\end{array}$ & $\begin{array}{l}0.027765 \\
\pm 0.000078\end{array}$ & $\begin{array}{l}0.008924 \\
\pm 0.000082\end{array}$ & $\begin{array}{c}8.070951 \\
\pm 1.458960\end{array}$ & $207.5 \pm 8.7$ & $\begin{array}{l}1.059583 \\
\pm 0.009793\end{array}$ & $\begin{array}{l}1.017905 \\
\pm 0.003469\end{array}$ & $>350,000$ & & $>350,000$ & \\
\hline
\end{tabular}


All ages were corrected for the detrital contribution of $U$ and Th to the samples. The detrital contribution used in this study assumes that all ${ }^{232} \mathrm{Th}$ measured is of detrital origin, that the detritus is in secular equilibrium and that the 'clays' extracted to provide a Th/U ratio for the calculation were representative of the likely detrital contamination for all samples. The ${ }^{232} \mathrm{Th} /{ }^{238} \mathrm{U}$ ratio of the detritus in samples from Orjen was 2.47 and this value was applied to correct the U-series ages. All the sites on Orjen are lithologically similar and thus the detrital contribution at all localities would be expected to be similar. When using alpha spectrometry techniques to determine U-series ages, samples with ${ }^{230} \mathrm{Th} /{ }^{232} \mathrm{Th}$ ratios $>20$ were considered 'clean' with no need for correction (Schwarcz, 1989). However, more precise results using mass spectrometry means that all U-series ages should be corrected for contamination and calcite samples are now considered 'clean' only when ${ }^{230} \mathrm{Th} /{ }^{232} \mathrm{Th}$ ratios are $>300$ (Hellstrom, 2006). The ${ }^{230} \mathrm{Th} /{ }^{232} \mathrm{Th}$ of the samples ranged from 3.9 to 207.5 (with 8 out of 12 ages $>20$ ) and, thus, all required correction. However, the corrected ages are only quoted in this paper when there is a significant disparity in ages, such as when the corrected age falls outside of the error of the uncorrected age. Both uncorrected and corrected ages are presented in Table 2 .

\section{Results - geomorphology, geochronology, chronostratigraphy}

\subsection{Geomorphology}

The bedrock geomorphology of Orjen is characterised by welldeveloped karstic landforms including dolines, shafts and deep cave systems (Tisserant, 1974; Groupe Spéléologique Muséum National d'Histoire Naturelle, Paris, 2003; Stepišnik et al., 2009) which are typical of the limestone mountains in the Mediterranean (Lewin and Woodward, 2009). In many valleys glacial erosion has moulded the limestone surfaces to form limestone pavements (Fig. 2) and dissected the massif forming cirques and glacial valleys on all slope orientations. Diamicton deposits containing predominantly subrounded and striated clasts with strong clast fabrics dipping towards the centre of the Orjen massif are present in all the major valleys of this area. In some areas these diamicton deposits form clear arcuate ridges visible from aerial photographs (Fig. 3). Down-valley of these diamicton deposits, spreads of sand and gravel are common, such as at Kameno and in the Dvrsno basin (Fig. 1). The diamicton deposits and associated ridges are interpreted as glacial in origin confirming the earlier observations of Grund (1910), Sawicki (1911) and Menković et al. (2004). Four separate sets of moraines are present at different positions on Orjen from the lowest valleys to the highest cirques. The glacial stratigraphical sequence is described below, starting with the lowest and most extensive moraines.

\subsubsection{Knežlaz Member}

Large moraine crests (up to $50 \mathrm{~m}$ high) are present in many of the lower valleys of Orjen (Fig. 2). These are situated at a range of altitudes between 500 and $1300 \mathrm{~m}$. The lowest moraines occur in the valleys that drain into the Adriatic Sea, in the southern part of the massif, and reach down to altitudes between 500 and $600 \mathrm{~m}$ above sea level immediately above the coastal towns of Herceg Novi (Fig. 4) and Risan (Fig. 1). Some of the largest moraines are present near the village of Knežlaz, above Risan, and this area represents the type area for the Knežlaz Member, which includes the lowest and oldest moraines on Orjen.

To the north of Knežlaz, in the eastern area of Orjen, large moraines are present in numerous valleys including those near

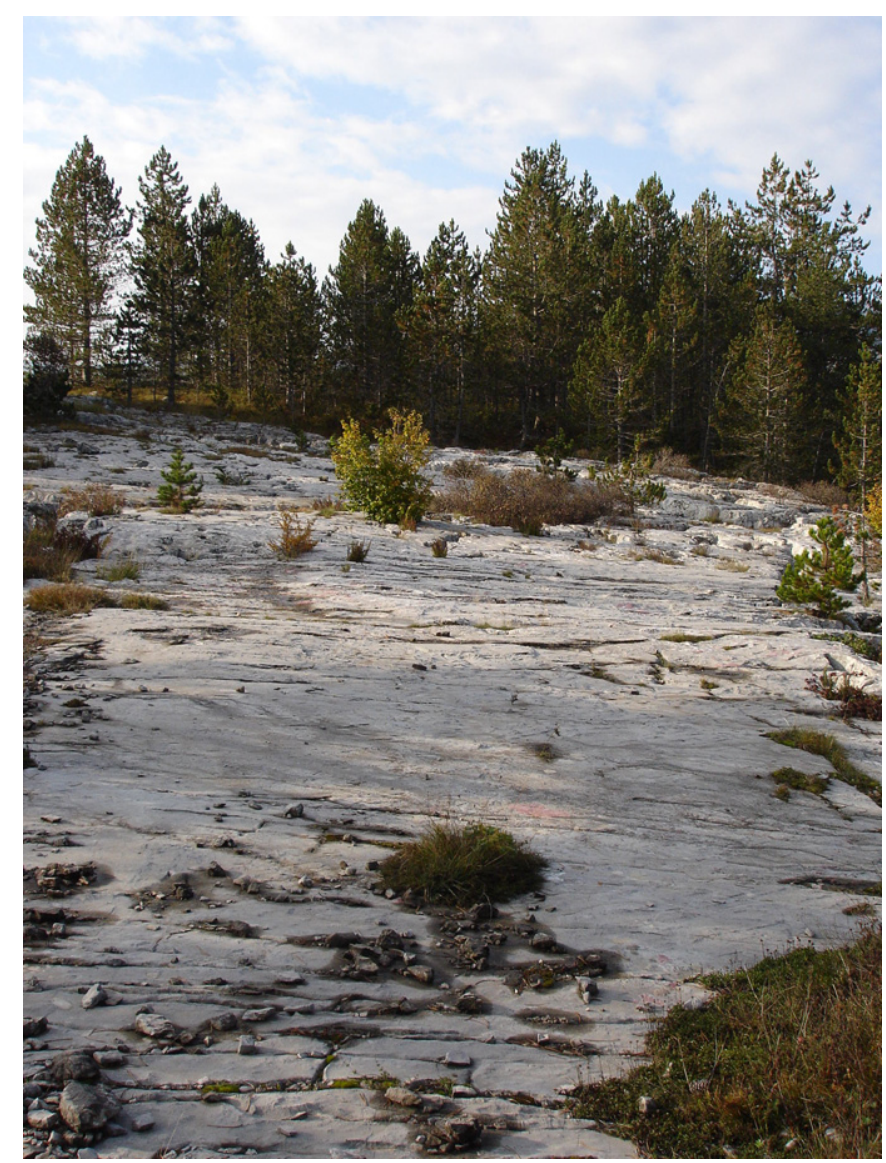

Fig. 2. Ice moulded limestone pavement in the Bijela Gora region of northern Orjen (see Fig. 1).

the villages of Malov do and Kulina. Below these two villages, large areas of gently sloping sand and gravel are present in the Dvrsno polje, displaying crudely stratified, waterlain characteristics. Similar deposits are also present in the Grahovo polje. In places, such as at Kulina, these gravel spreads merge into moraines and the former are interpreted as glaciofluvial outwash fans. Large outwash fans have also formed below the moraines at Kameno in the south and also below the moraines near Ždrijelo and Pirinia poljana in the west (Fig. 1). The northern limits of glaciation on Orjen are found in the area known as the Bijela Gora and moraines are present in three areas above the Nudo valley and the northern Grahovo polje (Fig. 5). Large moraines formed in the western valleys of Orjen, such as those at the entrance to the Pirina poljana valley in Bosnia (Fig. 2). Similar moraines are also present in the lower parts of valleys to the west of the highest peak of Orjen (Zubački Kabao, $1894 \mathrm{~m}$ ) and Subra (1679 m) (Fig. 1).

Pavements and perched boulders are present on some summits, ridges and cols as high as $1600 \mathrm{~m}$ in the central part of the massif. This evidence suggests that ice submerged and overran some summits, ridges and cols (Figs. 6 and 7). Aerial photographs indicate streamlining of bedrock surfaces to the east of the main Orjen watershed and over the Bijela Gora. Exceptions include the long sharp arête of Reovačka Greda (1769 m), which separates glaciated terrain in the Bijela Gora from the Reovci valley (Fig. 1).

Soils are particularly well-developed on the moraines of the Knežlaz Member (Fig. 8) and 5 sites (Kameno, Ubli, Knežlaz, Malov do, Bijela Gora) yielded a mean Profile Development Index (PDI) value of 56.7 . 


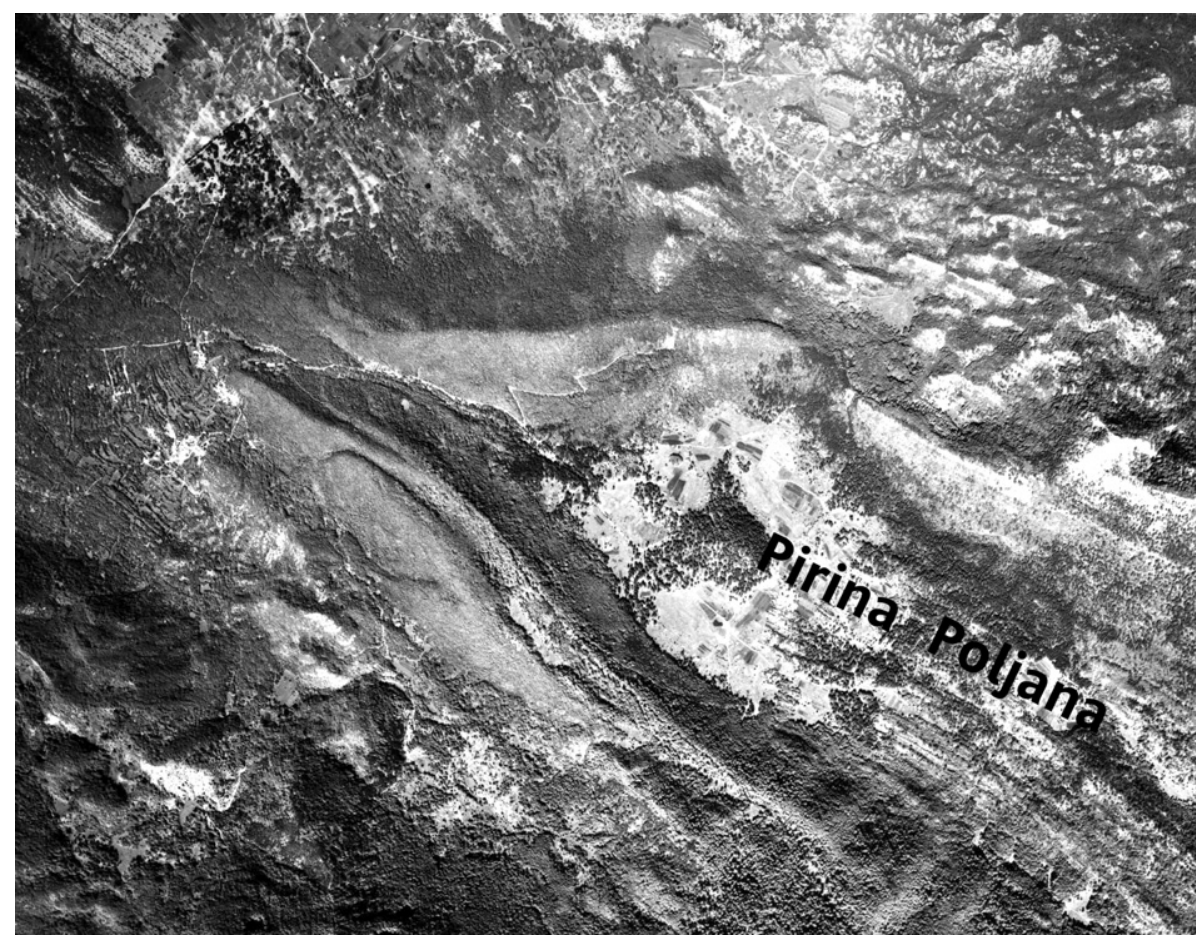

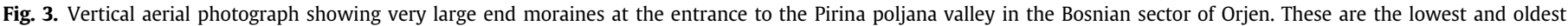
moraines in this area. For scale see Fig. 1 (unit 1 moraines in Pirina poljana). This image covers an area of approximately $5 \mathrm{~km} \times 4 \mathrm{~km}$.

\subsubsection{Crkvice Member}

Moraines also occur several kilometres up-valley of the outermost limits of glaciation and in several valleys, clusters of moraines can be identified in multiple valleys in mid-valley positions between altitudes of c 1000-1500 m (Fig. 1). The type area for these deposits is Crkvice, where clear moraine mounds and ridges are present. The Crkvice moraines are situated c. $5 \mathrm{~km}$ up-valley and 450 m higher than the limits of the Knežlaz Member.

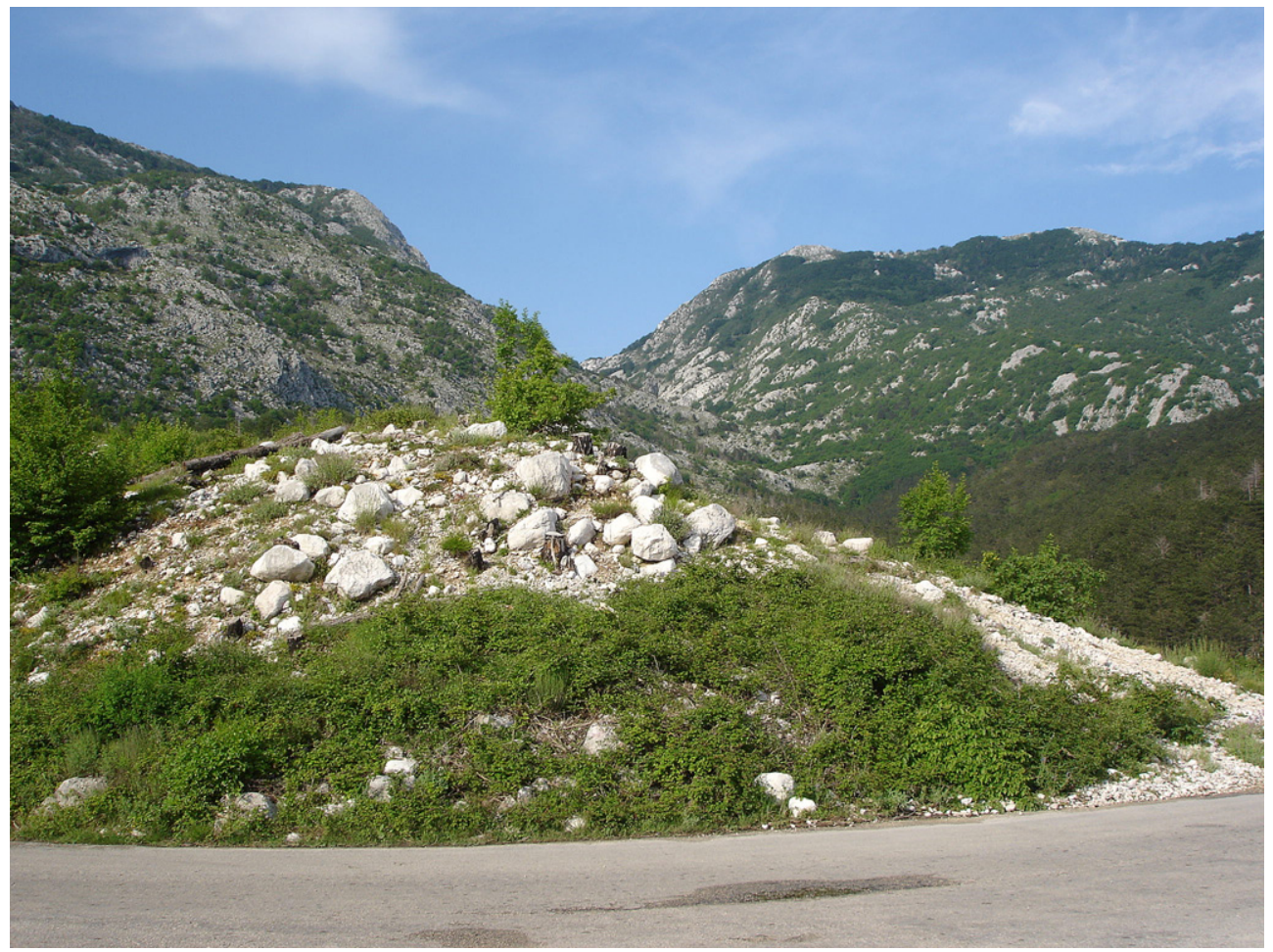

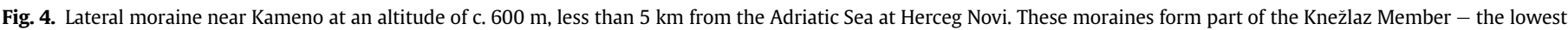
moraines on Orjen - and were formed at the margins of an outlet glacier that drained through the col in the background. 


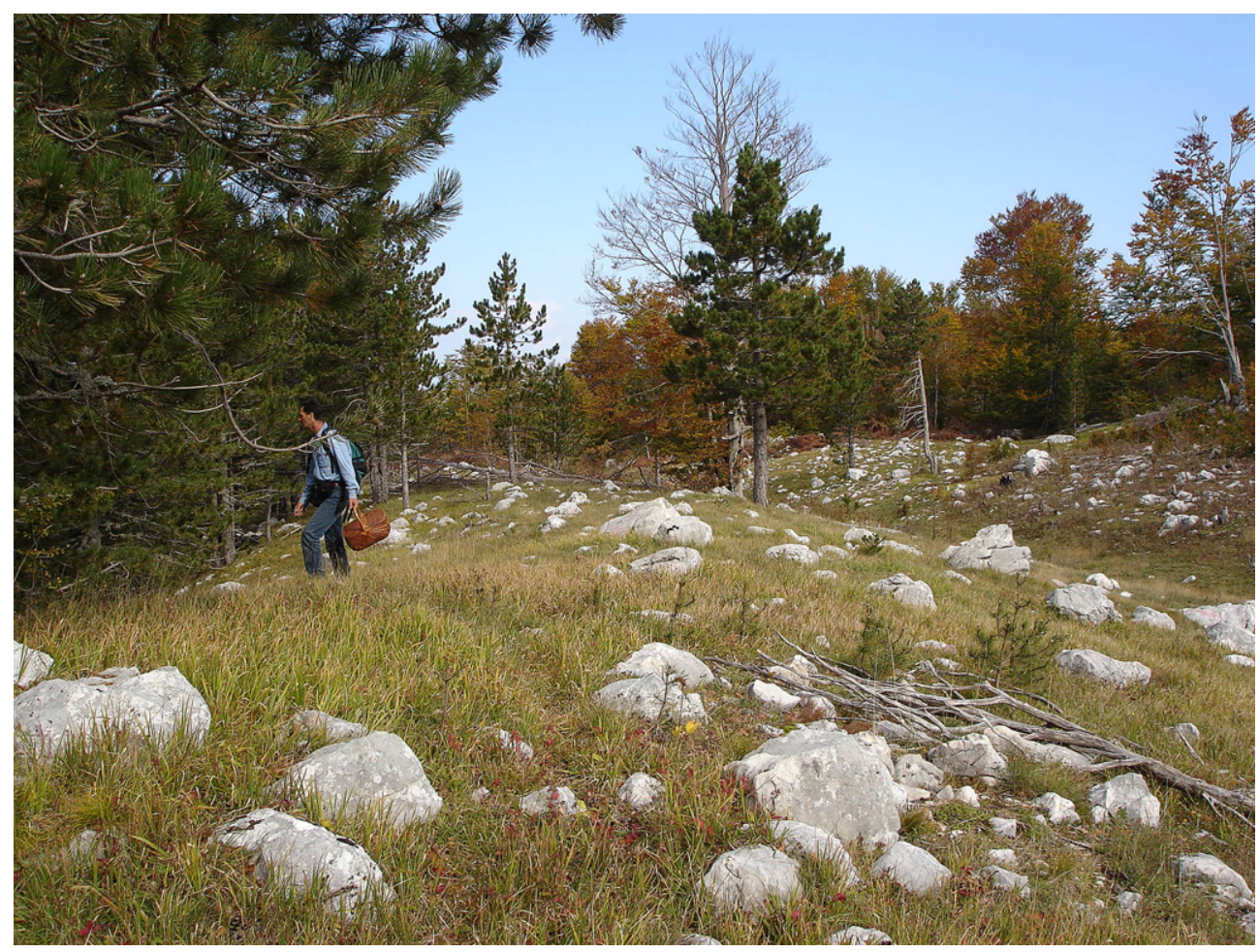

Fig. 5. Moraines in the remote Bijela Gora region. These moraines belong to stratigraphical unit 2 (Crkvice Member) in Fig. 1.

Moraines equivalent to those at Crkvice are present in almost every valley on Orjen (Fig. 9). In some areas the distance and altitude difference between these moraines and the lowermost moraines belonging to the Knežlaz Member is equal to or larger than at
Crkvice. This is the case in the neighbouring valleys at Brezov do and Ubajska planina and also in the valleys of the eastern Bijela Gora and the Pirina poljana valley (Fig. 1). However, in some areas, the distance and altitude difference between Crkvice Member moraines

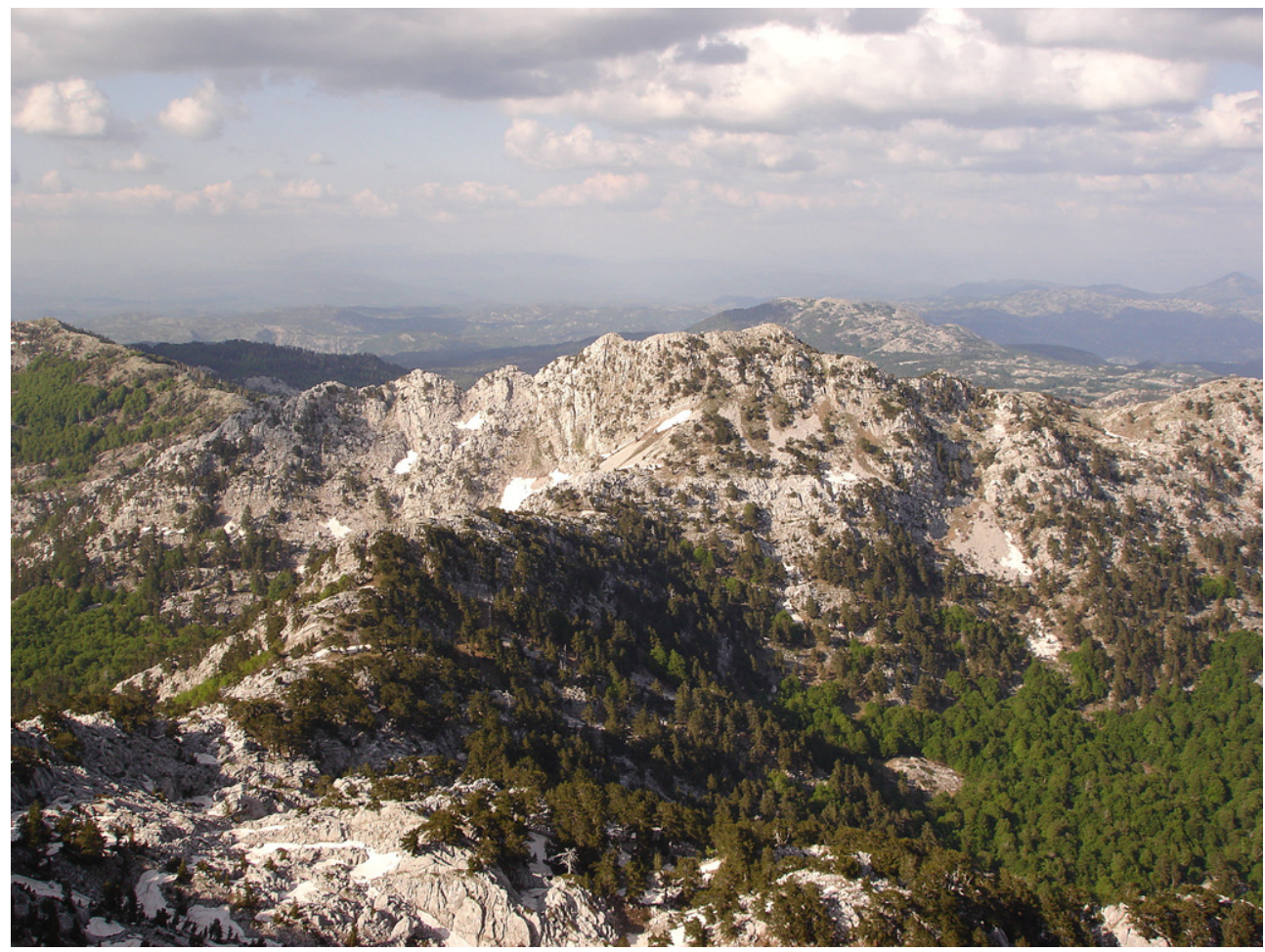

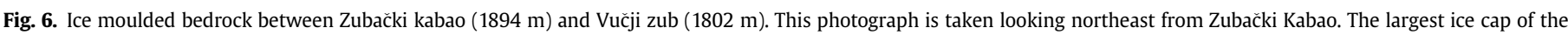
Middle Pleistocene was situated just to the right (east) of this col and ice would have flowed from right to left (east to west) into the valley of Pirina poljana (see Fig. 12). 


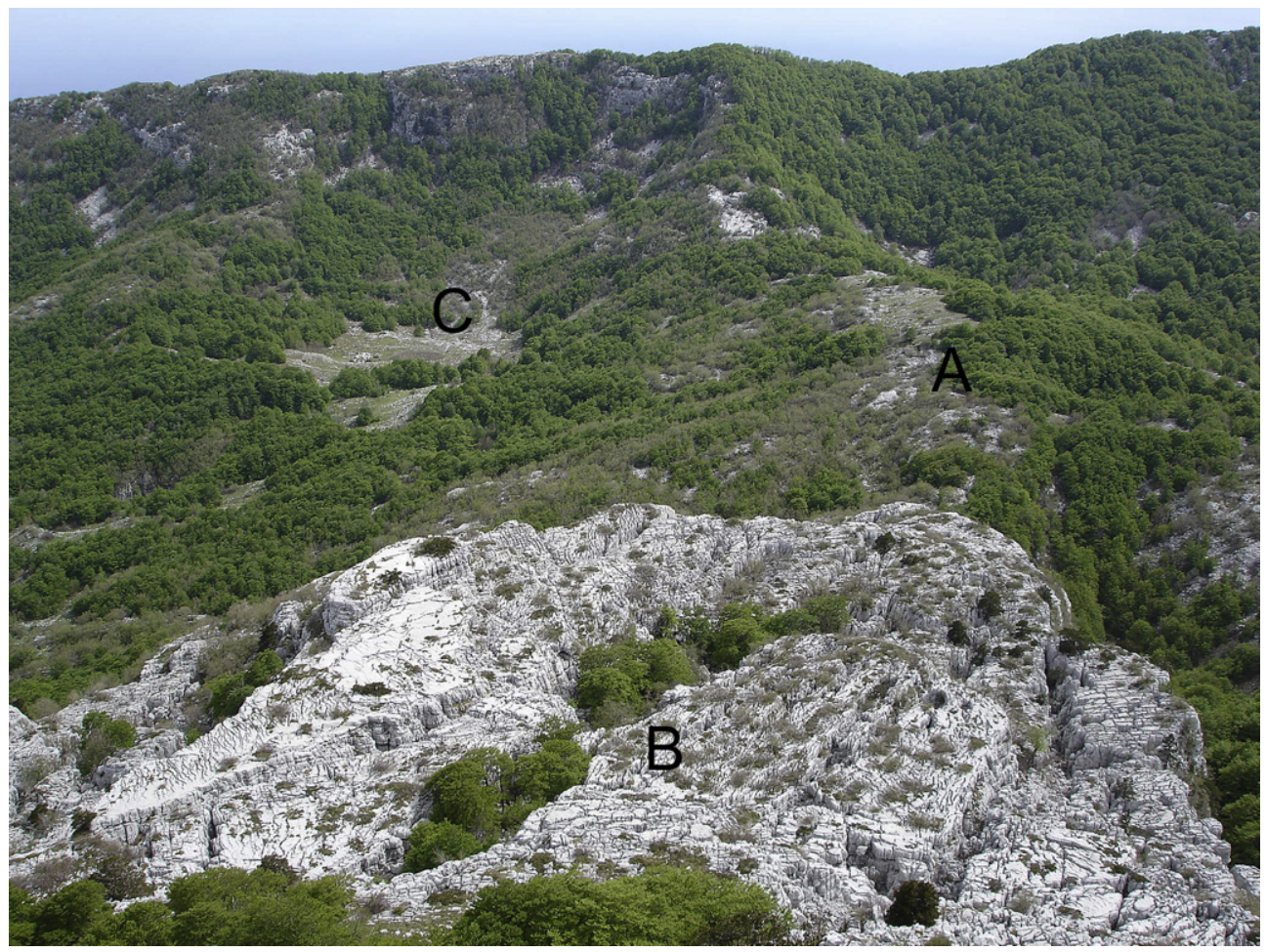

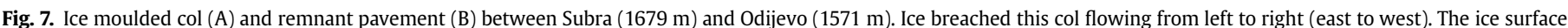

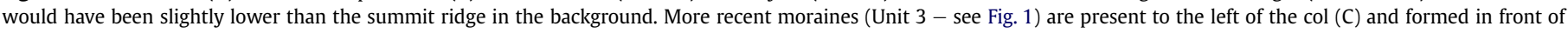
a small glacier below the cliffs in the background.

and lower Knežlaz Member moraines is quite small. At Ubli in southern Orjen, for example, moraines ascribed to the Crkvice Member are less than $100 \mathrm{~m}$ higher and less than $2 \mathrm{~km}$ up-valley of the lowest Knežlaz Member moraines (Fig. 1). In the western valleys of Orjen, moraine sequences are similarly closely spaced, but here the valleys are much shorter and steeper than elsewhere.

The mean PDI on moraines of the Crkvice Member was 34.5. This mean is based on soil profiles on Crkvice Member moraines to the southeast of Subra above Kameno, at Ubli, Crkvice, Malov do, and in the Bijela Gora (Fig. 1).

\subsubsection{Reovci Member}

Further sets of moraines are present at the heads of valleys and in cirques at altitudes ranging from 1200 to $1600 \mathrm{~m}$. The type area for these moraines is at Reovci, where a concentration of welldefined moraine mounds and ridges are situated approximately

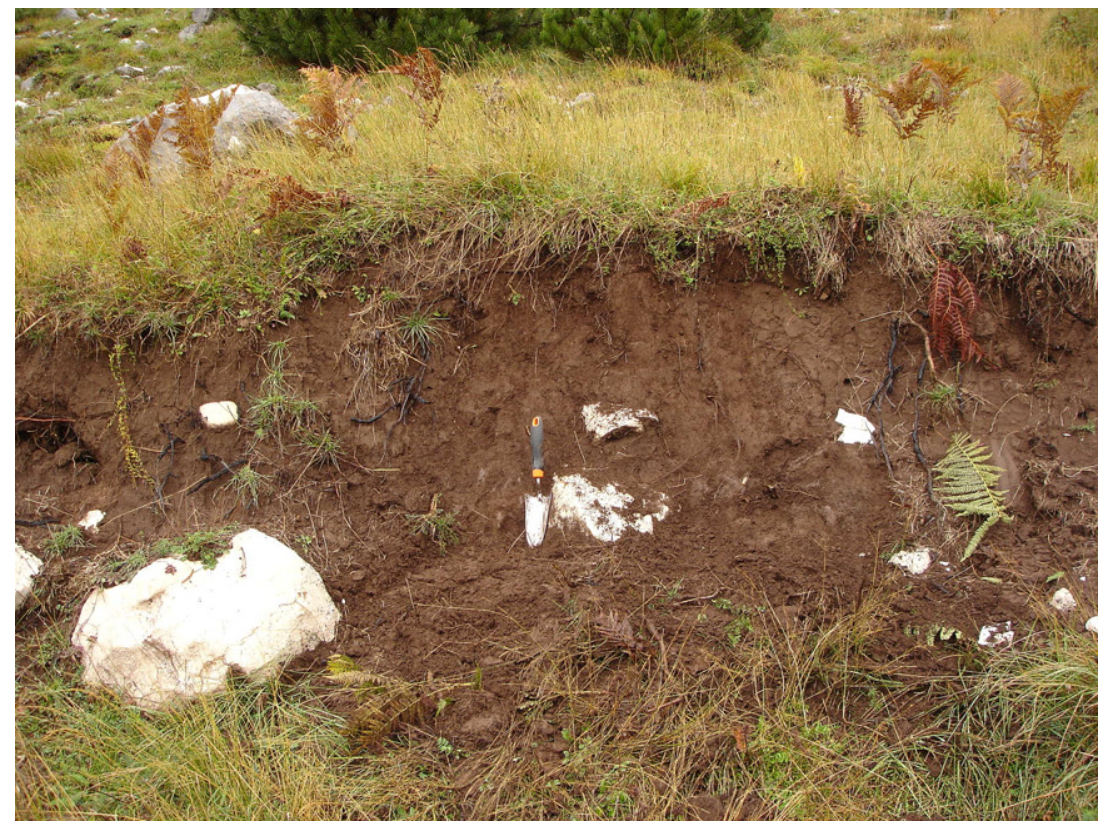

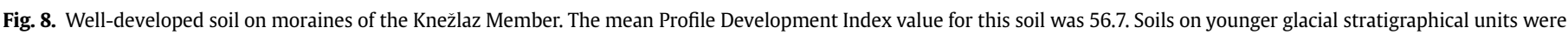
progressively thinner and less well-developed. 


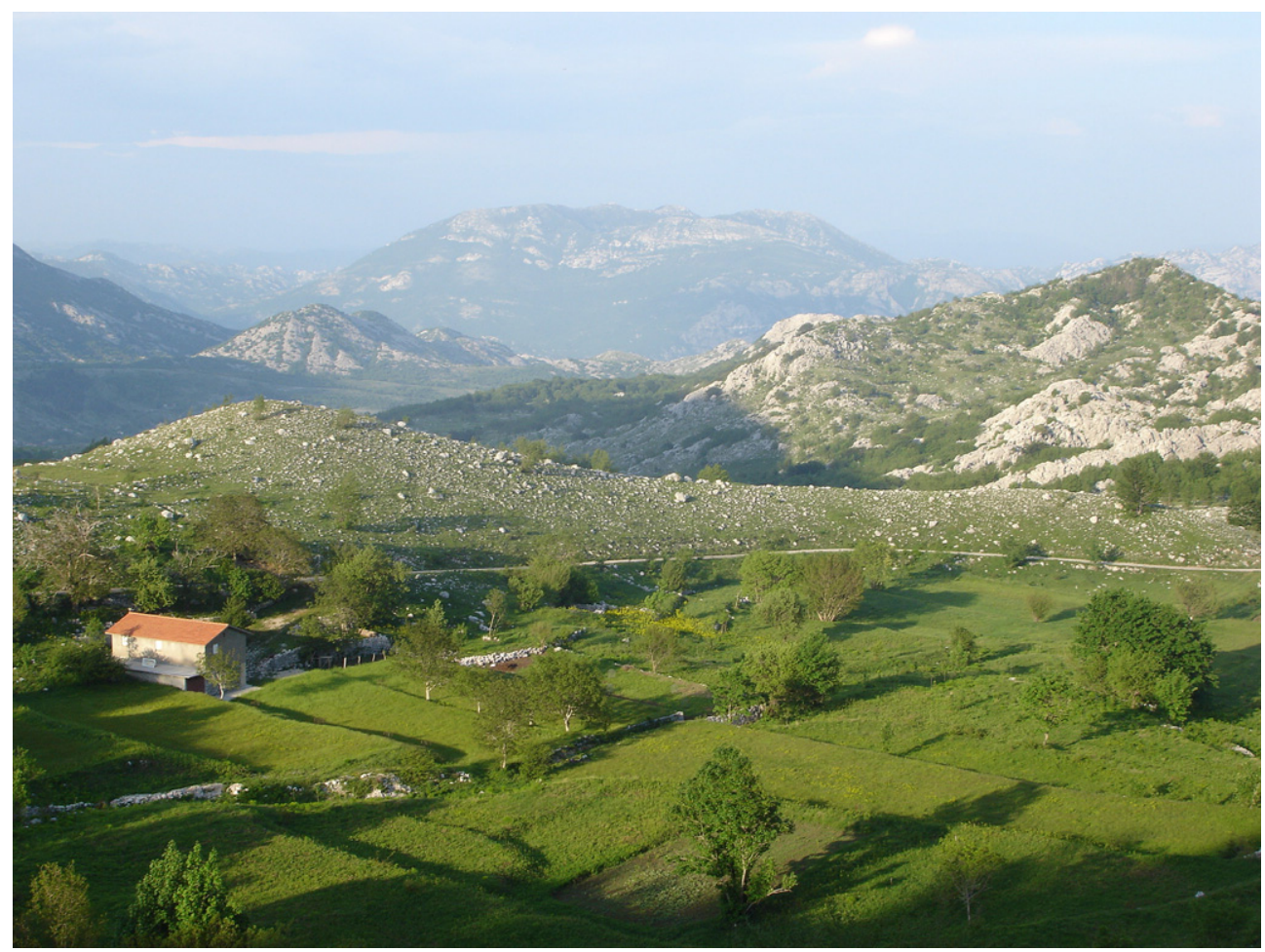

Fig. 9. Moraines belonging to the Crkvice Member near Sniježnice, above Ubli. These moraines contain secondary calcites that have yielded U-series ages of $102.4 \pm 3.1$ ka and $124.6 \pm 5.7 \mathrm{ka}$ (samples M2 and M16) - see Fig. 11.

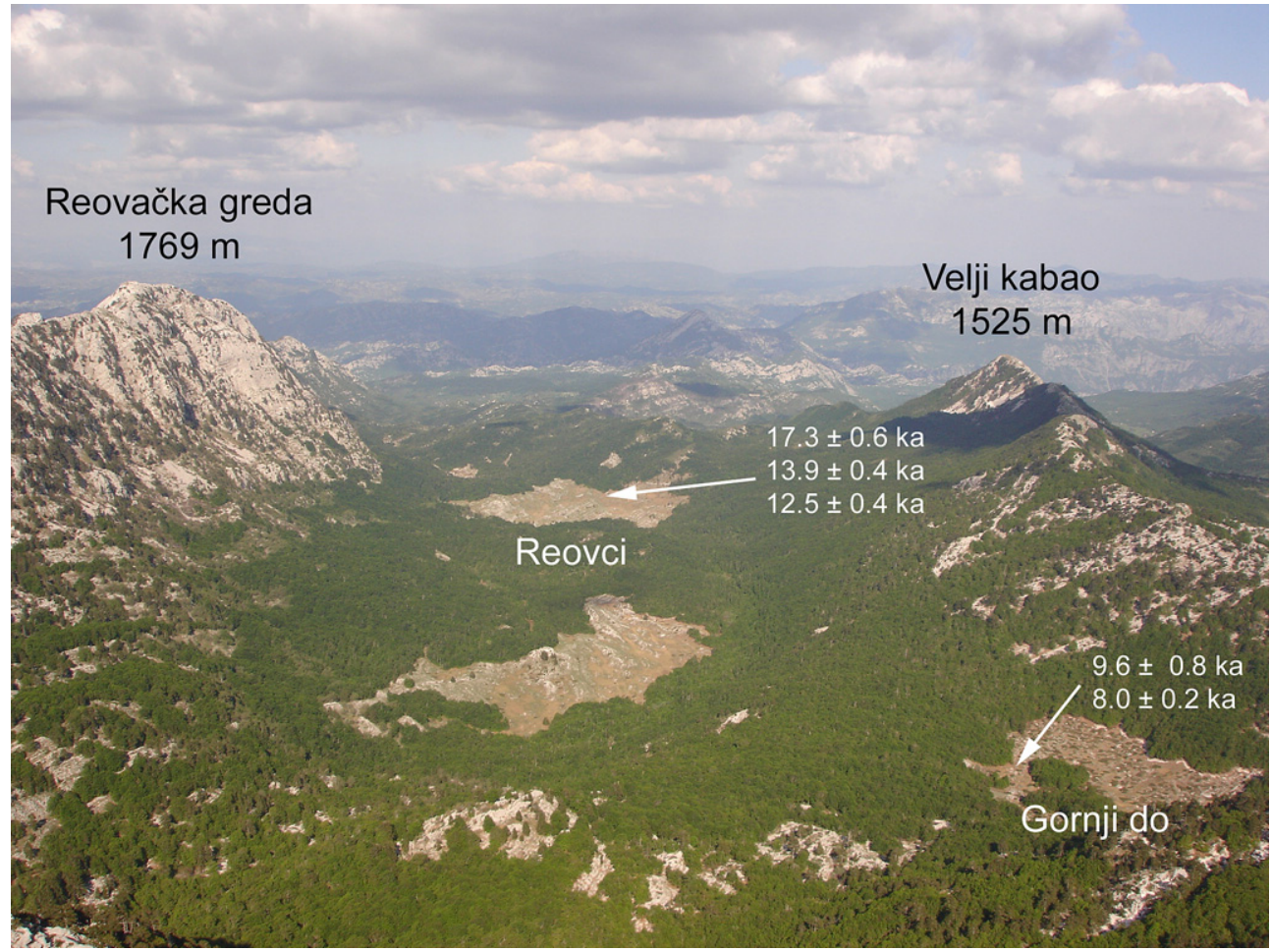

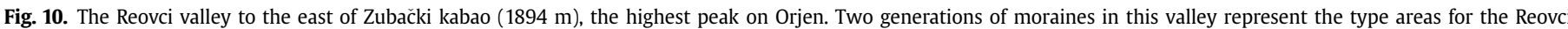

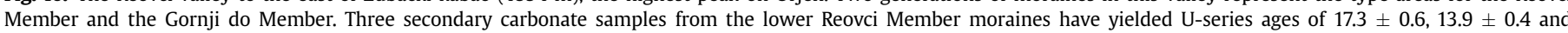

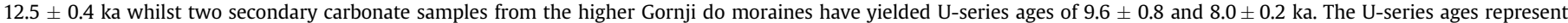

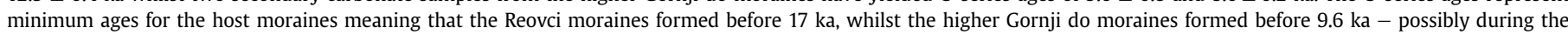
Younger Dryas. 
$4 \mathrm{~km}$ up-valley and $200 \mathrm{~m}$ higher than the moraines at Crkvice (Fig. 10).

Moraines equivalent to the Reovci Member are present in several other areas. However, in all other areas the glacial unit corresponding to the Reovci Member in the stratigraphical sequence is closer to the valley head and often within a cirque basin. Examples include the well-developed moraines in the cirques around the peaks of Vučji zub (1802 m), Zubački Kabao (1894 $\mathrm{m})$ and Subra (1679 m).

In comparison to moraines further down-valley soils are thinner on these moraines and the mean PDI value for the moraines of the Reovci Member was 14.7. This is based on soil sequences on the Reovci Member moraines at Reovci itself, cirque moraines above Kameno, and also at Borovi do in the Bijela Gora (Fig. 1).

\subsubsection{Gornji do Member}

In most valleys on Orjen no more than three discrete sets of moraines can be clearly distinguished. However, a fourth set is present in the upper reaches of the Reovci-Crkvice-Knežlaz valley (Fig. 10). The type area for these deposits is in the Gornji do basin, a northeast-facing depression below the pass of Orjen Sedlo between the peaks of Golišavac $(1722 \mathrm{~m})$ and Zubački Kabao $(1894 \mathrm{~m})$. Boulder-covered mounds and ridges are visible in the basin floor, which is treeless, and also at the basin lip.

As with the moraines of the Reovci Member, soils are relatively thin compared with the moraines further down-valley and the mean PDI value for the moraines of the Gornji do Member was 14.3.

\subsection{Geochronology}

A total of 12 secondary calcite samples were dated using U-series. These ages provide minimum ages for the host moraines (Woodward et al., 2004; Hughes et al., 2006c). The dates from the different glacial stratigraphical units on Orjen are described below and the isotope data are presented in Table 2.

\subsubsection{Knežlaz Member}

Three separate calcite samples were dated from moraines belonging to the Knežlaz Member, the lowest glacial unit on Orjen. Two samples (M18 and M29) yielded U-series ages of $>350 \mathrm{ka}$ and another (M10) yielded an age of $324.0 \pm 31.4 \mathrm{ka}$. The samples were taken from moraines in 3 different valleys: M18 from moraines near the village of Knežlaz; M29 from moraines below the village of Ubli; and, M10 from the lowest moraines in the Bijela Gora region of northern Orjen (Table 2 and Fig. 1). The ${ }^{230} \mathrm{Th} /{ }^{232} \mathrm{Th}$ ratio of 208 for sample M29 was the highest of all the samples from Orjen. The ${ }^{230} \mathrm{Th} /{ }^{232} \mathrm{Th}$ ratios for M18 and M10 were much lower, suggesting these samples had greater detrital contamination. Nevertheless, the U-series age for M18 is still infinite after correction (>350 ka) whilst the corrected age for M10 lies within the error of the uncorrected age (Table 2).

\subsubsection{Crkvice Member}

Four samples (M1, M2, M16, M19) from higher mid-valley moraines (Crkvice Member), up-valley of the Knežlaz Member moraines, yielded ages of $124.5 \pm 3.5,102.4 \pm 3.1,124.0 \pm 3.4$ and $124.6 \pm 5.7 \mathrm{ka}$ (corrected age) respectively. M1 was taken from moraines near the village of Crkvice whilst M16 was taken from moraines at Malov do north of Crkvice (Fig. 1). M2 and M19 were taken from moraines just to the north of Sniježnice (1104 m) (Figs. 9 and 11). The corrected age of $124.6 \pm 5.7 \mathrm{ka}$ from sample M19 is from a sample with a low ${ }^{230} \mathrm{Th} /{ }^{232} \mathrm{Th}$ ratio (3.8) but fits well with the uncorrected ages $(124.5 \pm 3.5,124.0 \pm 3.4 \mathrm{ka})$ from the cleaner sample in the same stratigraphical unit in the Crkvice and Malov do areas (Table 3).

\subsubsection{Reovci Member}

Further up-valley from Crkvice, within moraines of the Reovci Member secondary calcites were found in two different locations on the same end moraines (M7, M8 \& M27). These yielded U-series ages of $13.9 \pm 0.4,12.5 \pm 0.4$ and $17.3 \pm 0.6 \mathrm{ka}$, respectively. Two

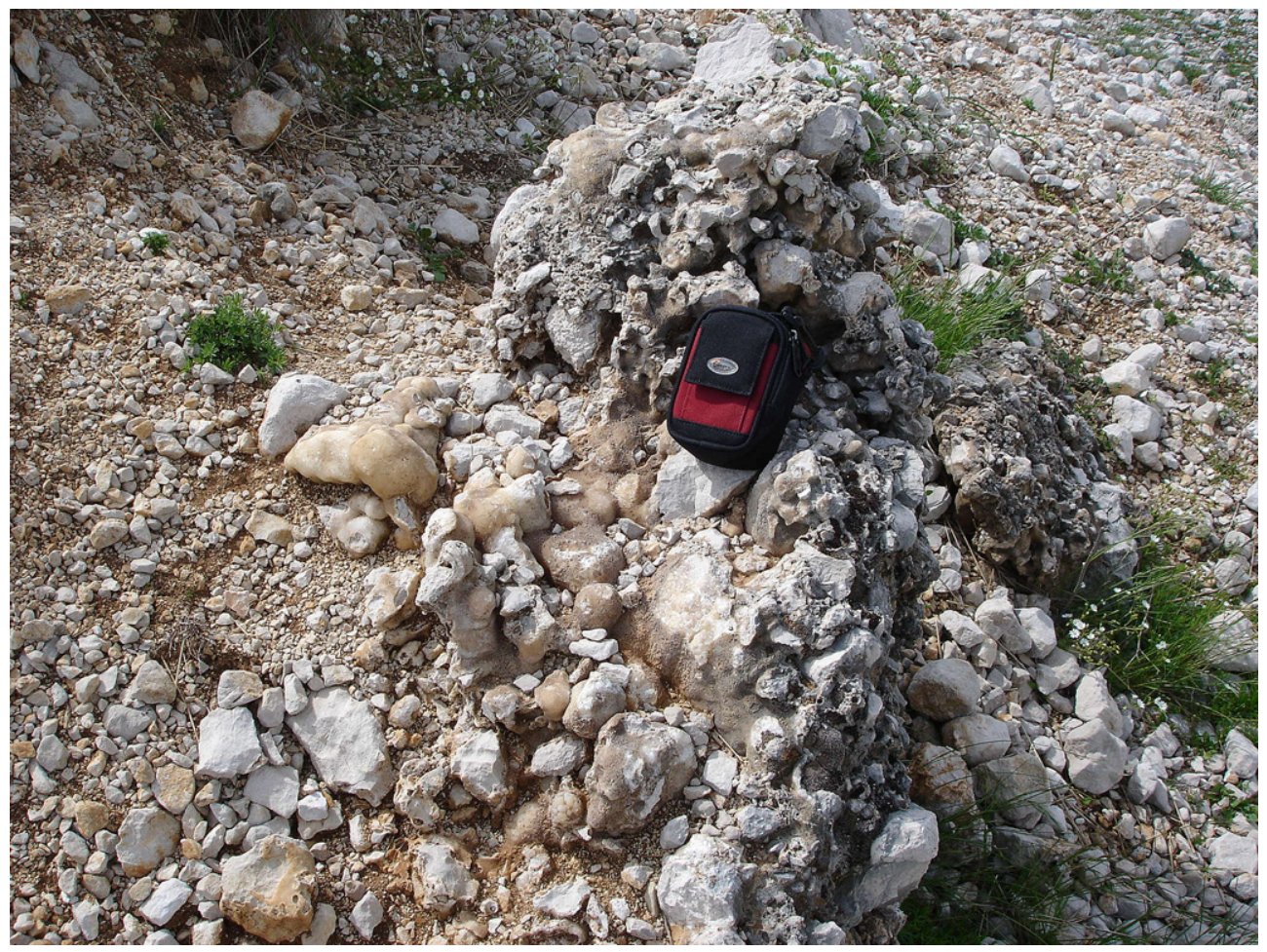

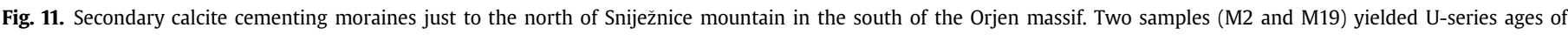
$102.4 \pm 3.1$ and $124.6 \pm 5.7 \mathrm{ka}$, respectively. 
Table 3

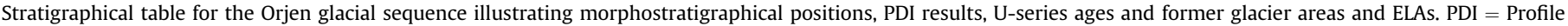
Development Index. ELA = equilibrium line altitude.

\begin{tabular}{|c|c|c|c|c|c|c|c|}
\hline $\begin{array}{l}\text { Stratigraphical } \\
\text { unit }\end{array}$ & $\begin{array}{l}\text { U-series ages } \\
\text { (ka) }\end{array}$ & $\begin{array}{l}\text { Soil } \\
\text { PDI }\end{array}$ & Chronostratigraphy & $\begin{array}{l}\text { Number of } \\
\text { glaciers }\end{array}$ & $\begin{array}{l}\text { Total former } \\
\text { glacier area }\left(\mathrm{km}^{2}\right)\end{array}$ & $\begin{array}{l}\text { Mean Glacier } \\
\text { ELA }(\mathrm{m})\end{array}$ & Characteristics \\
\hline Knežlaz Member & $\begin{array}{l}>350 \\
>350 \\
324.0 \pm 31.4\end{array}$ & 56.7 & MIS 12 & 2 & 165.41 & 1256 & $\begin{array}{l}\text { Ice cap with outlet glaciers }+ \text { one } \\
\text { valley glacier }\end{array}$ \\
\hline Crkvice Member & $\begin{array}{l}124.6 \pm 5.7^{\mathrm{a}} \\
124.5 \pm 3.5 \\
124.0 \pm 3.4 \\
102.4 \pm 3.1\end{array}$ & 34.5 & MIS 6 & 16 & 84.89 & 1424 & $\begin{array}{l}\text { Ice cap over Bijela Gora. Valley and cirque } \\
\text { glaciers elsewhere }\end{array}$ \\
\hline Reovci Member & $\begin{array}{l}17.3 \pm 0.6 \\
13.9 \pm 0.4 \\
12.5 \pm 0.4\end{array}$ & 14.7 & MIS 2 & 9 & 6.55 & 1456 & $\begin{array}{l}\text { Valley glacier at Reovci. Cirque glaciers } \\
\text { elsewhere }\end{array}$ \\
\hline Gornji do Member & $\begin{array}{l}9.6 \mathrm{ka} \pm 0.8 \\
8.0 \mathrm{ka} \pm 0.2^{\mathrm{a}}\end{array}$ & 14.3 & Younger Dryas & 1 & 1.04 & 1465 & Cirque glacier \\
\hline
\end{tabular}

${ }^{\text {a }}$ Corrected age.

samples (M7 \& M8) were taken from the same site where calcite had filled a void between boulders exposed in a section through the moraine. The calcite was laminated and c. $120 \mathrm{~mm}$ thick. The age of $13.9 \pm 0.4 \mathrm{ka}(\mathrm{M} 7)$ is from the base laminae of the sample closest to the lower boulder whilst the age of $12.5 \pm 0.4 \mathrm{ka}$ (M8) is from the top laminae of the sample. All of the samples had ${ }^{230} \mathrm{Th} /{ }^{232} \mathrm{Th}$ ratios $>40$ and the corrected ages were close to and within the error of the uncorrected ages.

\subsubsection{Gornji do Member}

The highest cirque moraines on Orjen contain secondary calcites no older than the early Holocene. Two calcite samples (M15 \& M21) from Gornji do yielded ages of $9.6 \pm 0.8 \mathrm{ka}$ (uncorrected age) and $8.0 \pm 0.2 \mathrm{ka}$ (corrected age). The former sample had a ${ }^{230} \mathrm{Th} /{ }^{232} \mathrm{Th}$ ratio of 50.0 and the corrected age was close to the uncorrected age, whilst the latter corrected sample had $\mathrm{a}^{230} \mathrm{Th} /{ }^{232} \mathrm{Th}$ ratio of just 4.2 and required correction.

\subsection{Glacial chronostratigraphy}

Whilst the precise timing of glaciation within different Pleistocene cold stages cannot be discerned using this approach, the U-series ages enable the four glacial stratigraphical units to be bracketed in time and support the stratigraphical subdivision based on both morphostratigraphy and pedostratigraphy (Table 3).

Soil profiles contrasted markedly between the lowermost moraines (Knežlaz Member) and the higher moraines (Crkvice and Reovci Members). The mean PDI value for the Knežlaz Member was 56.7, whilst on the Crkvice Member moraines it was 34.5 and 14.7 on the Reovci Member moraines. This suggests that the different sets of moraines are widely separated in time and not recessional moraines that formed within the same glacial cycle. In fact, the PDI values are similar to those found on different moraines, widely separated in age, in northern Greece (Hughes et al., 2006c). A similar situation on Orjen is tested here using the U-series data.

The U-series dating indicates that the most extensive glaciation of Orjen occurred before $350 \mathrm{ka}$. It is possible that this event occurred during one of the Middle Pleistocene cold stages: MIS 18, 16,14 or 12 . An Early Pleistocene age for the most extensive glacial deposits on Orjen is unlikely since, in many areas, moraines are wellpreserved. In fact, the excellent preservation of some of the most extensive moraines would favour the youngest of the cold stages identified above: MIS 12; and this cold stage was proposed for the most extensive phase of glaciation (Skamnellian Stage) in the Pindus Mountains, Greece (Woodward et al., 2004; Hughes et al., 2006c).

In common with the Pindus Mountains, later glaciations were less extensive than the largest ice cap glaciation. The oldest U-series ages from the mid-valley moraines (unit 2 in Fig. 1) date from the Last Interglacial. Thus, the host moraines must have formed earlier, but later than the older more extensive ice cap moraines. The absence of ages older than the Last Interglacial suggest that this phase of mid-valley glaciation occurred during MIS 6, correlating with a similar phase of mid-valley glaciation in Greece during a cold stage defined as the Vlasian Stage (Hughes et al., 2006c).

The last two phases of glaciation on Orjen date from the last cold stage (MIS 5d-2), equivalent to the Tymphian Stage in Greece (Hughes et al., 2006c). Only small cirque and valley glaciers survived on Orjen during the last cold stage. Glaciers in the highest valley areas appear to have retreated from their maximum positions by c. $17 \mathrm{ka}$. The last glacier to form on Orjen did so in the doline of Gornji do, immediately east of the highest peak Zubački kabao. The early Holocene ages for secondary calcites within these moraines are consistent with the hypothesis that the last glaciers on Orjen existed during the Younger Dryas (12.9-11.7 ka).

\section{Glacier-climate reconstruction}

\subsection{Methods}

Palaeoglaciers of different ages were reconstructed based on the geomorphological and geochronological evidence. The ice cap surface was reconstructed using a parabolic equation devised to produce surface profiles for ice sheets resting on flat horizontal beds (Cowton et al., 2009). The surface contours of the ice cap were drawn perpendicular to the former ice flow direction, which was inferred from the geomorphological evidence. The surface contours of outlet, valley and cirque glaciers were constrained by topography and geomorphological evidence such as the position of moraines and trimlines. A variation of the accumulation area ratio (AAR) method was applied to reconstruct the equilibrium line altitude (ELA). It was refined using the methods outlined by Osmaston (2002) for the Rwenzori Mountains of Uganda and later applied to palaeoglaciers in Greece by Hughes et al. (2007). In this approach the most appropriate ELAs are found by choosing the accumulation area ratio (AAR) with the lowest standard deviation in a sample of glaciers (see Fig. 14). The corresponding AAR value is most likely to represent the regional equilibrium line altitude (ELA). In the case of single ice caps drained by multiple outlet glaciers, the ice cap was subdivided into sectors separated by ice sheds and treated as individual glacier entities for the purposes of ELA reconstruction (cf Cowton et al., 2009).

A simple degree-day model (Brugger, 2006; Hughes, 2008) was used to calculate the amount of accumulation required to sustain the former glaciers on Orjen. This approach uses specified inputs of 
mean annual temperature and mean annual temperature range. These annual temperatures were then distributed over a sine curve to provide daily temperature means using the following equation (from Brugger, 2006; Hughes, 2008):

$T_{\mathrm{d}}=A_{\mathrm{y}} \sin (2 \pi d / \lambda-\Phi)+T_{\mathrm{a}}$

where $T_{\mathrm{d}}$ is the mean daily air temperature, $A_{\mathrm{y}}$ is the amplitude of the yearly temperature ( $1 / 2$ of the annual temperature range), $d$ is the day of the year (1-365), $\lambda$ is the period (365 days), $\Phi$ is the phase angle (taken as 1.93 radians to reflect the fact that January is the coolest month) and $T_{\mathrm{a}}$ is the mean annual air temperature.

The annual accumulation required at the different altitudes to balance melting equals the sum of daily snowmelt, using a degreeday factor. Braithwaite (2008) found that degree-day factors for snow on 66 glaciers worldwide had averages of $3.5 \pm 1.4$ and $4.6 \pm 1.4 \mathrm{~mm}$ day $^{-1}{ }^{\circ} \mathrm{K}^{-1}$ in low- and high-accumulation conditions, respectively, with an overall mean of $4.1 \pm 1.5 \mathrm{~mm} \mathrm{day}^{-1}{ }^{\circ} \mathrm{K}^{-1}$, in accordance with earlier values reported in the literature (e.g. Braithwaite et al., 2006). Thus, a degree-day factor of $4.1 \mathrm{~mm}$ day $^{-1}{ }^{\circ} \mathrm{K}^{-1}$ was used in the simple degree-day model.

Under equilibrium conditions (zero mass balance) snowmelt must equal snow accumulation at the ELA. Snowmelt at the reconstructed ELAs on Orjen was simulated under different temperature regimes in order to understand the climates required to sustain glaciers in this area. Climate data from Crkvice $(940 \mathrm{~m}$; Table 1) on the eastern slopes of Orjen was used in the climate modelling. Modern temperatures at this station were depressed by $5-15{ }^{\circ} \mathrm{C}$ in $1{ }^{\circ} \mathrm{C}$ intervals and then extrapolated to the mean reconstructed ELAs on Orjen during different glacial phases using a lapse rate of $0.6{ }^{\circ} \mathrm{C}$. The degree-day model was then run at the reconstructed ELAs of the different glacial phases producing a range of temperature-accumulation predictions. However, the degreeday model also requires an input for mean annual temperature range. Various authors (Hughes and Braithwaite, 2008; Hughes, 2009a; Golledge et al., 2009) have demonstrated that combination values of annual temperature and accumulation at glacier ELAs are dependent on mean annual temperature range, which determines the length of the melt season. The modern (1931-1960) mean annual temperature range at Crkvice is $18.7^{\circ} \mathrm{C}$. The model was run using this value and also $28.1{ }^{\circ} \mathrm{C}$, which represents $150 \%$ of the modern mean annual temperature range. This is to reflect the possibility that climate is likely to have been more continental during Pleistocene cold stages since sea levels were lower $(120 \mathrm{~m}$ lower during the last cold stage) and large areas of the Adriatic basin were land, especially in the north (van Andel and Shackleton, 1982; Correggiari et al., 1996). This is reflected by the presence of fluvial deposits in the Boka Kotorska embayment immediately off Orjen (Bortoluzzi et al., 2009).

\subsection{Results}

The stratigraphical and geochronological evidence described above provides the basis for the reconstruction of four different generations of glaciers (Figs. 12 and 13). The glaciers are described below with reference to the glacial stratigraphical units which represent them.

\subsubsection{Knežlaz Member glaciers (Skamnellian Stage, MIS 12)}

The oldest and most extensive glaciation was characterised by an ice cap which covered large areas of Orjen (Fig. 12). A small valley glacier also formed to the north of Jastrebica (1865 m). The ice cap and valley glacier covered a total area of $165.4 \mathrm{~km}^{2}$. The ice cap was centred to the east of the highest peak of Orjen, Zubački Kabao and submerged the peak of Vučji zub (1802 m) with the central dome of the former ice cap reaching an elevation of $\mathrm{c}$. $1950 \mathrm{~m}$ above present sea level. Outlet glaciers drained the ice cap radially with major lobes extending over the northern and eastern parts of Orjen. A large outlet glacier also drained northwestwards through the Pirina poljana valley and several valley glaciers drained into the western and southern valleys of Orjen. The lowest glacier limits occurred in the south near Kameno and in the east below Knežlaz where the ice terminated at an altitude between 500 and $600 \mathrm{~m}$. The thickest area of the former ice cap occurred in the upper Reovci valley, approximately $1-2 \mathrm{~km}$ southeast of the ice cap centre.

The accumulation area ratio (AAR) with the lowest standard deviation for the 11 sectors of the ice cap and the Jastrebica valley glacier was 0.8 (Fig. 14). Leonard (1984, p. 68) stated that "the appropriate AARs for ice caps and piedmont glaciers are unknown", but noted that AARs for ice caps may be as high as 0.8 . This is supported by the results from Orjen and this AAR value is consistent with AARs calculated for some modern ice caps (Meier and Post, 1962; Burgess and Sharp, 2004). For the ice cap and glacier delimited by the Knežlaz Member moraines an AAR of 0.8 corresponds to an equilibrium line altitude (ELA) of $1256 \mathrm{~m}$.

\subsubsection{Crkvice Member glaciers (Vlasian Stage, MIS 6)}

The moraines of the Crkvice Member delimit 16 former ice fields and glaciers which covered a total area of $84.9 \mathrm{~km}^{2}$ (Fig. 13). The largest glacier formed over the Bijela Gora plateau, where a $29 \mathrm{~km}^{2}$ ice field developed to the northeast of Vučji zub (1802 m) and drained north and east towards the Nudo valley and Dvrsno basin, respectively. Large valley glaciers also formed in the Reovci, Brezov do valleys and over the Ubajska planina plateau draining towards Ubli. Numerous smaller ice fields and glaciers formed in the southern and western valleys too.

The AAR with the lowest standard deviation for the 16 ice fields and glaciers was 0.6 (Fig. 14), which is consistent with the typical AAR found on modern valley glaciers (Porter, 1975). On the Orjen glaciers delimited by the moraines of the Crkvice Member, this AAR corresponded to an ELA of $1424 \mathrm{~m}$. The asymmetrical U-shape of the standard deviation curve, is similar to the findings of Osmaston (2002), with lowest standard deviations for the highest parts of glaciers $(A A R=1)$ compared with the snouts $(A A R=0)$. This reflects the fact that source area altitudes for glaciers tend to be similar in any given mountain area since this is associated with cirque headwalls, whilst snout altitudes tend to be highly variable because of variations in glacier hypsometry.

\subsubsection{Reovci Member glaciers (Tymphian Stage, MIS 5d-2)}

At least nine small glaciers formed during the largest glacial advance of the last cold stage and covered a total area of $6.55 \mathrm{~km}^{2}$ with an ELA of $1424 \mathrm{~m}$ (Fig. 13). The largest glacier formed in the upper Reovci valley and covered an area of $3.19 \mathrm{~km}^{2}$. All of the other glaciers had surface areas of $<2 \mathrm{~km}^{2}$. The standard deviations of the AARs for the Reovci Member glaciers were lowest for an AAR of 0 and steadily increased towards an AAR of 1 . This reflects the fact that the source areas of the former glaciers were at a similar altitude whilst the snouts had greater altitudinal variability. This pattern suggests that these glaciers all existed below the regional ELA, which would have been close to the summit altitudes, and that variability in snout altitudes reflects glacier hypsometry and local topoclimate controls such as windblown snow and avalanche inputs. In modern settings small cirque glaciers such as these often experience negative balance over the whole glacier in some years and positive mass balance in others (Hughes, 2008). This variability in mass balance in response to inter-annual climate variability means that defining the ELA year-on-year is difficult. The median altitude of the glacier surface (AAR $=0.5$ ) has been used on modern 


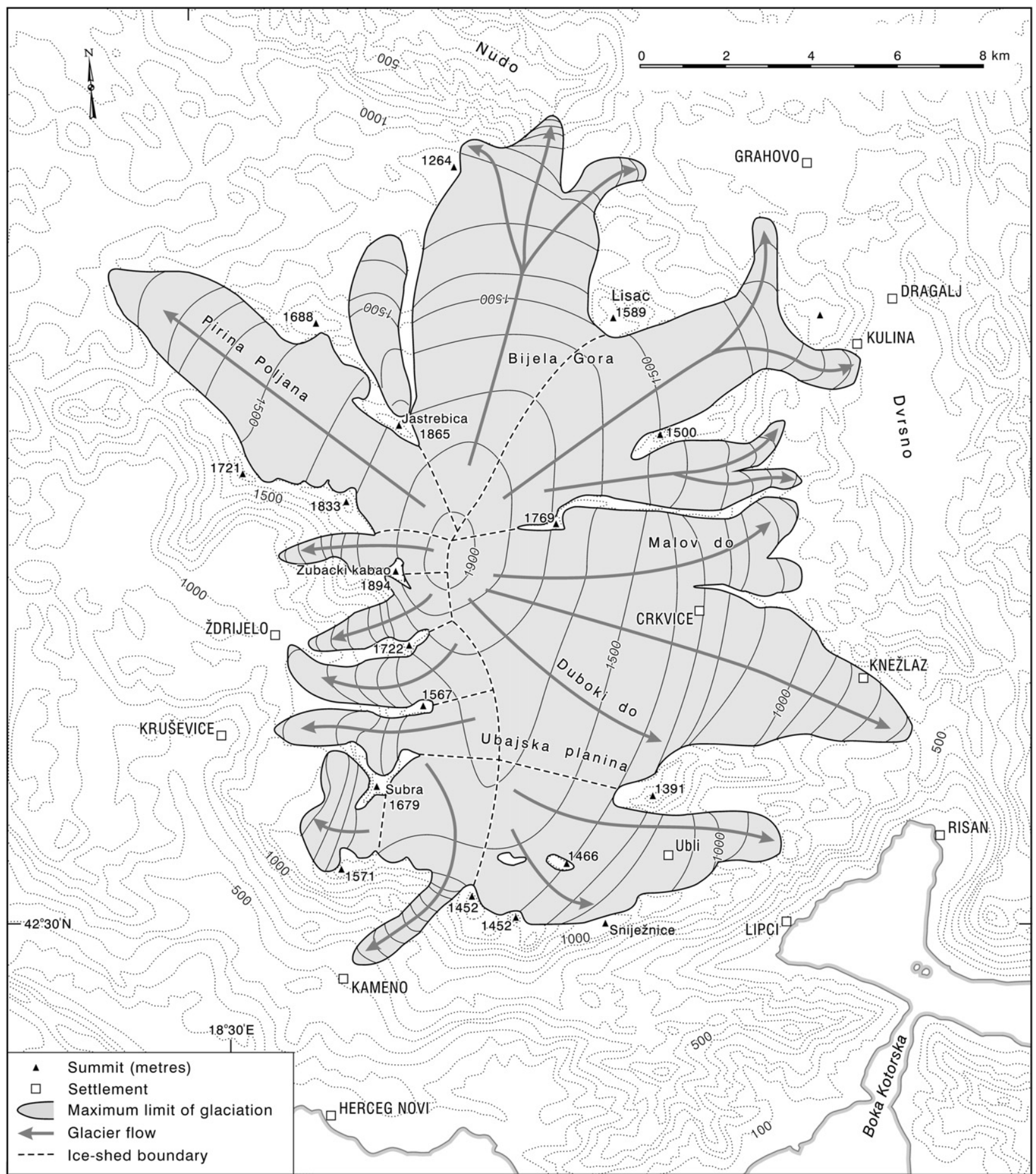

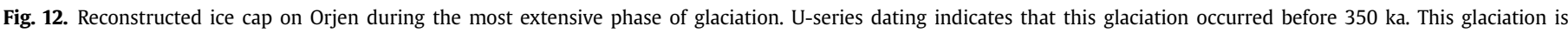

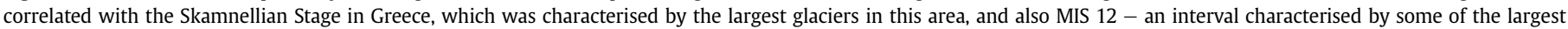
glaciations elsewhere in Europe (Ehlers and Gibbard, 2008) and one of the most severe cold stages in the Balkans (Tzedakis et al., 2003; Tzedakis, 2005).

glaciers in Montenegro and Albania (Hughes, 2008, 2009b) and the distribution of standard deviations for the different AARs for the Orjen glaciers during this stage suggests that this approach is the most appropriate in this case too.

\subsubsection{Gornji do Member glacier (Younger Dryas)}

Only one glacier is ascribed to the Younger Dryas. This glacier occupied Gornji do to the east of Zubački kabao, the highest peak on
Orjen (Figs. 10 and 13). This glacier covered an area of just over $1 \mathrm{~km}^{2}$ and was situated at a relatively low altitude compared with some of the Reovci Member glaciers. Using an AAR of 0.5 this glacier had an ELA of $1465 \mathrm{~m}$, which is only slightly above the mean ELA of the Reovci glaciers calculated using the same AAR. This may reflect local topoclimatic controls since the Gornji do glacier is situated in a northeast-facing depression in the lee of elevated plateau surfaces to the south and southwest, which would have promoted the 

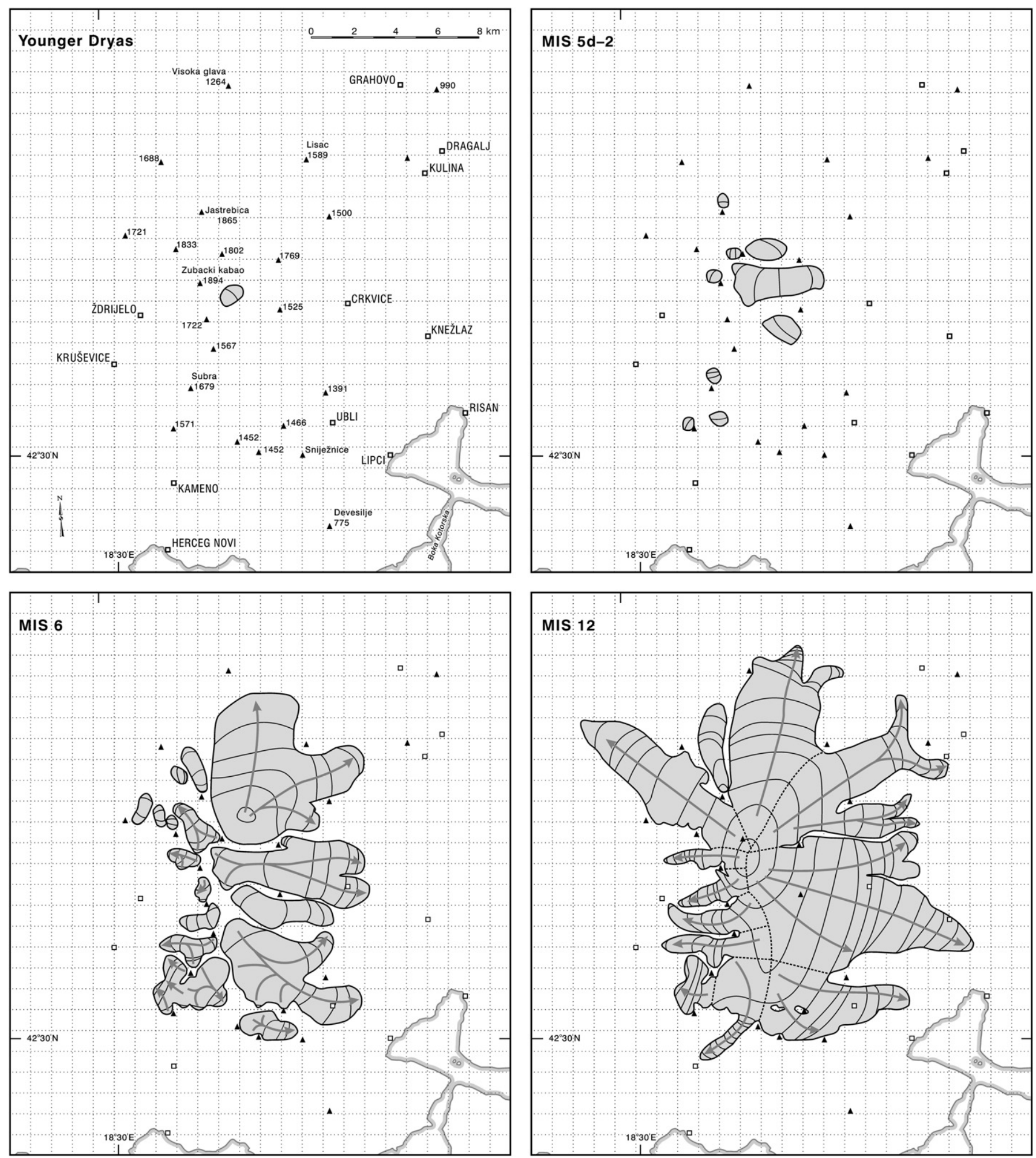

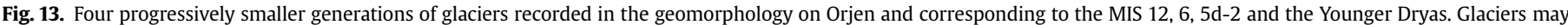
have also existed during earlier and intervening cold stages, but there is no evidence of this, and glaciers must have been smaller in size than later glacial advances.

lee-side accumulation of windblown snow. In addition, the western side of the Gornji do doline is bounded by steep, avalanche-prone cliffs, rising to Zubački kabao (1894 m). Windblown and avalanching snow are often suggested as a major contributory factors for the formation and sustenance of former glaciers in many mountains at altitudes close to the threshold for glaciation (Mîndrescu et al., 2010). Indeed, both windblown and avalanching snow are known to be important for recent and existing glacier survival in the Durmitor and Prokletije areas of Montenegro and Albania - especially in northeast-facing cirques (Hughes, 2009b, 2010). 

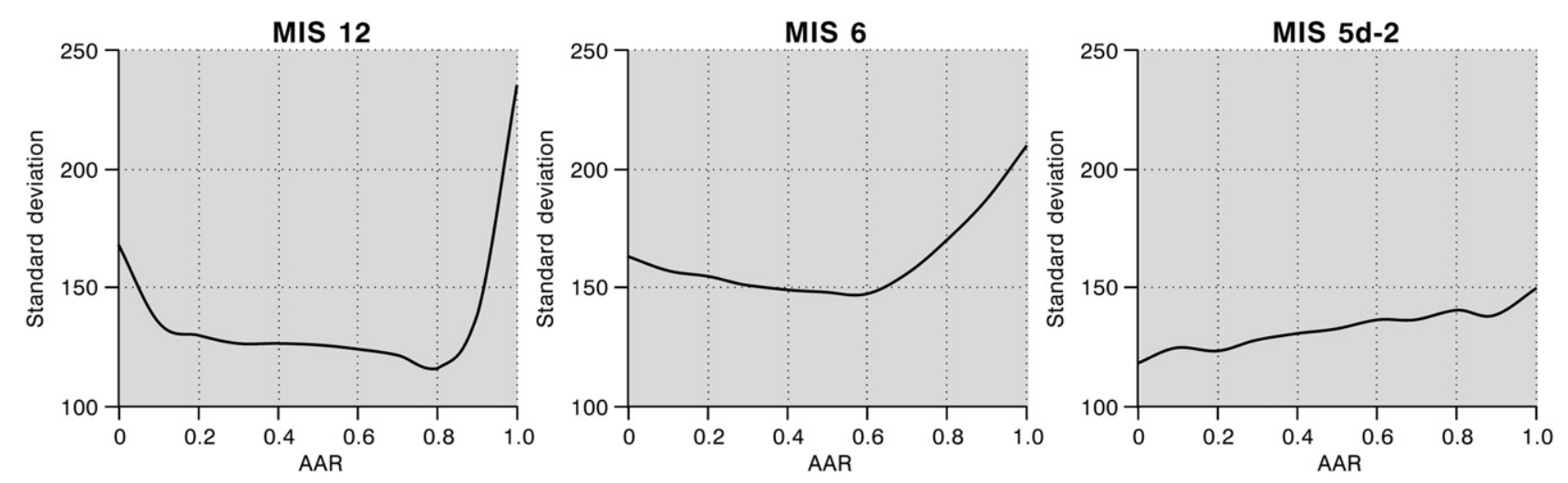

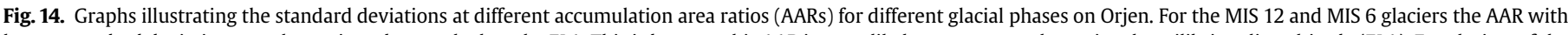

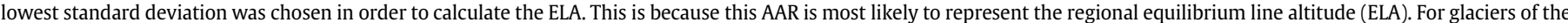

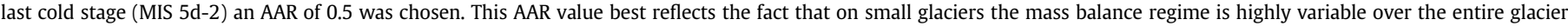
surface year-on-year. See text for details.

\subsubsection{Palaeoclimate}

The results of the degree-day model simulations are presented in Table 4 . The temperature-melt reconstructions are simulated under the modern mean annual temperature range. Higher temperature ranges require even higher accumulation to balance melting because summer temperatures are higher and this is illustrated by the very high melt predictions when the annual temperature range is $150 \%$ of the modern value (Table 4 ). As noted earlier, lower cold stage sea levels would have exposed large areas of land in the Adriatic basin resulting in greater continentality and higher mean annual temperature ranges. This means that the melt simulations associated with a modern annual temperature range of $18.7{ }^{\circ} \mathrm{C}$ in Table 4 are minimum estimates.

Table 4

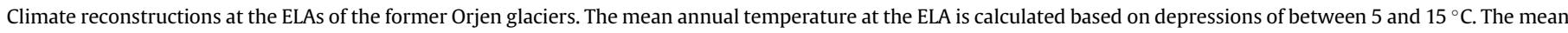

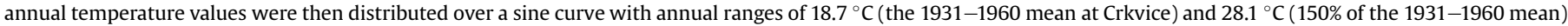

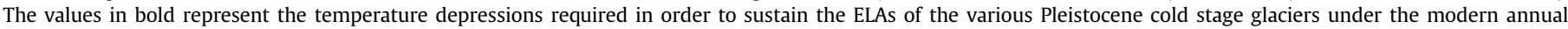

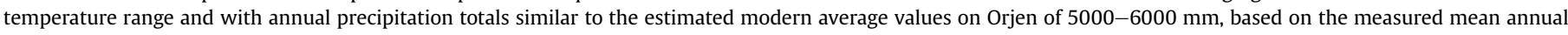
precipitation value of $4926 \mathrm{~mm}$ (1931-1960) at Crkvice (940 m).

\begin{tabular}{|c|c|c|c|c|}
\hline \multirow{2}{*}{$\begin{array}{l}\text { Temperature } \\
\text { depression }\left({ }^{\circ} \mathrm{C}\right)\end{array}$} & \multirow{2}{*}{$\begin{array}{l}\text { Mean annual } \\
\text { temperature } \\
\text { at ELA }\left({ }^{\circ} \mathrm{C}\right)\end{array}$} & \multirow[t]{2}{*}{ Cold stage } & \multicolumn{2}{|l|}{ Annual melt (mm w.e.) } \\
\hline & & & Ann range $=18.7^{\circ} \mathrm{C}$ & $150 \%$ Ann range $=28.1^{\circ} \mathrm{C}$ \\
\hline \multirow[t]{3}{*}{$\downarrow 5$} & 4.3 & MIS $12(E L A=1256 \mathrm{~m})$ & 6589 & 8708 \\
\hline & & MIS $6(E L A=1424 \mathrm{~m})$ & 5743 & 7901 \\
\hline & & MIS 5d-2 (ELA = $1456 \mathrm{~m})$ & 5580 & 7744 \\
\hline \multirow[t]{3}{*}{$\downarrow 6$} & 3.3 & MIS $12(E L A=1256 \mathrm{~m})$ & 5743 & 7901 \\
\hline & & MIS $6(E L A=1424 \mathrm{~m})$ & 4948 & 7128 \\
\hline & & MIS 5d-2 (ELA = $1456 \mathrm{~m})$ & 4795 & 6977 \\
\hline \multirow[t]{3}{*}{$\downarrow 7$} & 2.3 & MIS $12($ ELA $=1256 \mathrm{~m})$ & 4948 & 7128 \\
\hline & & MIS $6(E L A=1424 \mathrm{~m})$ & 4202 & 6387 \\
\hline & & MIS 5d-2 (ELA = $1456 \mathrm{~m})$ & 4059 & 6243 \\
\hline \multirow[t]{3}{*}{$\downarrow 8$} & 1.3 & MIS $12(E L A=1256 \mathrm{~m})$ & 4202 & 6387 \\
\hline & & MIS $6(E L A=1424 \mathrm{~m})$ & 3507 & 5680 \\
\hline & & MIS $5 \mathrm{~d}-2(\mathrm{ELA}=1456 \mathrm{~m})$ & 3374 & 5543 \\
\hline \multirow[t]{3}{*}{$\downarrow 9$} & 0.3 & MIS $12($ ELA $=1256 \mathrm{~m})$ & 3507 & 5680 \\
\hline & & MIS $6(E L A=1424 \mathrm{~m})$ & 2861 & 5006 \\
\hline & & MIS $5 \mathrm{~d}-2(E L A=1456 \mathrm{~m})$ & 2739 & 4875 \\
\hline \multirow[t]{3}{*}{$\downarrow 10$} & -0.7 & MIS $12(E L A=1256 \mathrm{~m})$ & 2861 & 5006 \\
\hline & & MIS $6(E L A=1424 \mathrm{~m})$ & 2268 & 4366 \\
\hline & & MIS 5d-2 (ELA $=1456 \mathrm{~m})$ & 2155 & 4242 \\
\hline \multirow[t]{3}{*}{$\downarrow 11$} & -1.7 & MIS $12(E L A=1256 \mathrm{~m})$ & 2268 & 4366 \\
\hline & & MIS $6(E L A=1424 \mathrm{~m})$ & 1726 & 3759 \\
\hline & & MIS 5d-2 (ELA = $1456 \mathrm{~m})$ & 1625 & 3642 \\
\hline \multirow[t]{3}{*}{$\downarrow 12$} & -2.7 & MIS $12(E L A=1256 \mathrm{~m})$ & 1726 & 3759 \\
\hline & & MIS $6(E L A=1424 \mathrm{~m})$ & 1241 & 3188 \\
\hline & & MIS 5d-2 (ELA = $1456 \mathrm{~m})$ & 1151 & 3077 \\
\hline \multirow[t]{3}{*}{$\downarrow 13$} & -3.7 & MIS $12(E L A=1256 \mathrm{~m})$ & 1241 & 3188 \\
\hline & & MIS $6(E L A=1424 \mathrm{~m})$ & 816 & 2656 \\
\hline & & MIS $5 \mathrm{~d}-2(E L A=1456 \mathrm{~m})$ & 738 & 2549 \\
\hline \multirow[t]{3}{*}{$\downarrow 14$} & -4.7 & MIS $12(E L A=1256 \mathrm{~m})$ & 816 & 2652 \\
\hline & & MIS $6(E L A=1424 \mathrm{~m})$ & 457 & 2152 \\
\hline & & MIS 5d-2 (ELA = $1456 \mathrm{~m})$ & 395 & 2057 \\
\hline \multirow[t]{3}{*}{$\downarrow 15$} & -5.7 & MIS $12(E L A=1256 \mathrm{~m})$ & 457 & 2152 \\
\hline & & MIS $6(E L A=1424 \mathrm{~m})$ & 178 & 1692 \\
\hline & & MIS 5d-2 (ELA = $1456 \mathrm{~m})$ & 133 & 1605 \\
\hline
\end{tabular}




\section{Discussion}

\subsection{The glacial history of Orjen: comparisons with other} Mediterranean mountains

The glaciation on Orjen (1894 $\mathrm{m})$ is striking because of its large extent and low altitude. In northern Croatian Dalmatia, c. $300 \mathrm{~km}$ to the northwest of Orjen, Marjanac and Marjanac (2004) have identified evidence of glaciation down to sea level on the western flanks of Vaganski vrh $(1757 \mathrm{~m})$ with moraines reported on the shores of Novigradsko More. Elsewhere, in Montenegro, Albania and Kosovo, several researchers have also reported evidence for very extensive glaciations, with former ice caps and large valley glaciers forming over the Planine Morača (Liedtke, 1962), Durmitor (Nicod, 1968) and the Prokletije (Cvijić, 1917). However, more recent papers have suggested a more limited glaciation characterised by Alpine-style cirque, valley and piedmont glaciers on Durmitor (Marović and Marović, 1972; Menković et al., 2004; Djurović, 2009), the Prokletije (Milivojević et al., 2008) and in the Šara Mountains (Kuhlemann et al., 2009). On Orjen, however, the evidence for extensive glaciation is abundant and unequivocal and this paper confirms the findings of the early pioneer studies of Grund (1910) and Sawicki (1911).

Comparisons with Pleistocene glaciation elsewhere in the Mediterranean mountains (Messerli, 1967; Hughes and Woodward, 2009 ) indicate that the Orjen ice cap represented one of the largest and lowest ice caps at this latitude in southern Europe during the Pleistocene. The largest phase of ice cap glaciation on Orjen (total area: $165.4 \mathrm{~km}^{2}$; mean ELA: $1256 \mathrm{~m}$ ) was more than twice the size of the total ice cover on Mount Tymphi $(2497 \mathrm{~m})$ in northwest Greece, $340 \mathrm{~km}$ to the southeast, and also several hundred metres lower (Tymphi; total area: $59.3 \mathrm{~km}^{2}$; ELA: $1741 \mathrm{~m}$ ). At a similar latitude to Orjen, glaciers in the Sanabria and Estrela National Parks of Spain and Portugal, respectively, were significantly higher with ELAs $>1500 \mathrm{~m}$, even when AARs as high as 0.8 are applied (Vieira, 2007; Cowton et al., 2009). Whilst the Orjen ice cap, with an area of at $165 \mathrm{~km}^{2}$, did not match the largest Sanabria ice cap (total area: $440 \mathrm{~km}^{2}$ ), it was more than twice the size of the ice cap on Portugal's Sierra da Estrela, which covered an area of $66 \mathrm{~km}^{2}$. However, the timing of these large former Iberian ice caps is not yet firmly established, although several ${ }^{21} \mathrm{Ne}$ and ${ }^{10} \mathrm{Be}$ exposure ages indicate a Middle Pleistocene age in some areas (Fernández-Mosquera et al., 2000; Vidal-Romaní and Fernández-Mosquera, 2006).

The U-series dates presented in this paper indicate that the oldest recorded glaciation, when an ice cap formed over much of Orjen, occurred before $350 \mathrm{ka}$. As noted earlier this glaciation can be correlated with the largest glaciation of Greece, during the Skamnellian Stage (MIS 12; 480-430 ka) (Hughes et al., 2006c; Woodward et al., 2008). In the Šara Mountains of Kosovo/ Macedonia, Kuhlemann et al. (2009) found evidence of only limited mountain glaciation and moraines have been dated (using ${ }^{10} \mathrm{Be}$ terrestrial cosmogenic nuclide analyses) to the Late Pleistocene. Kuhlemann et al. (2009) found no evidence of an older and more extensive glaciation. The U-series dates from two separate mountain areas of the eastern Mediterranean, Orjen in Montenegro and Tymphi in Greece, provide robust evidence for large Middle Pleistocene glaciations in the western Balkans.

There is evidence of at least two large Middle Pleistocene glaciations in all of these regions. The second, smaller glaciation, predates the Last Interglacial and, as on Tymphi, this glaciation can be ascribed to the Vlasian Stage (MIS 6; 190-130 ka). There is no evidence of glaciation between MIS 6 and MIS 12 on either Orjen or Tymphi. However, this is not to say that these mountains were not glaciated during MIS 8 and 10, but that the glaciers were smaller than the Vlasian Stage glaciers and the evidence has not been preserved.

As was the case on Mount Tymphi in northern Greece (Hughes et al., 2006b), the glaciers of the Late Pleistocene on Orjen were restricted to the highest valleys and cirques. In fact, the Orjen and Tymphi glaciers were similar in size covering a total area of just 6.6 and $3.9 \mathrm{~km}^{2}$, respectively, the larger total for Orjen resulting partly from the larger number of glaciers $(n=9)$ compared with Tymphi $(n=6)$. In contrast to Mount Tymphi, the moraines of the last cold stage on Orjen have been dated using U-series. The results indicate that glaciers had retreated from their maximum positions by $17 \mathrm{ka}$, which matches well with ${ }^{10} \mathrm{Be}$ ages (within error limits) from moraines in the Šara Mountains of Kosovo/Macedonia (Kuhlemann et al., 2009). Similarly, retreat of ice by this time agrees well with ${ }^{10} \mathrm{Be}$ and ${ }^{36} \mathrm{Cl}$ ages from the mountains of the Maritime Alps (Italy), Corsica and Turkey (Granger et al., 2006; Akçar et al., 2007, 2008; Kuhlemann et al., 2008; Sarlkaya et al., 2008, 2009). This is also in good agreement with the fluvial record from Northwest Greece (Woodward et al., 2008).

Perhaps one of the most interesting discoveries is the evidence of Younger Dryas glaciation on Orjen. There is clear evidence of only one former glacier for this period and two U-series ages from within its moraines point to a Younger Dryas age. Evidence of Younger Dryas glaciers elsewhere in Montenegro has also been found on Durmitor (Hughes and Woodward, 2008) and Hughes et al. (2006d) have argued that the last glaciers in northern Greece formed during this interval too. On Durmitor, in northern Montenegro, the Younger Dryas moraines are situated just $1 \mathrm{~km}$ down-valley of a currently active glacier - indicating that the former glacier was not much lower than the modern ice mass. During the Little Ice Age at least 8 glaciers were present on Durmitor (Hughes, 2010), although given the low altitude of Orjen it is very unlikely that glaciers have formed at any time since the Younger Dryas. The presence of Younger Dryas glaciers in the mountains of Montenegro is important because the evidence of this climate signal has been lacking or ambiguous in other palaeoenvironmental records in the Balkans - especially in pollen records (Bottema, 1995; Lawson et al., 2004) - whilst apparent in others, such as rockshelters and lacustrine diatom records (Karkanas, 2001; Wilson et al., 2008). The palaeoclimatic implications of all the glaciations on Orjen are discussed below.

\subsection{Implications for understanding Mediterranean palaeoclimates during cold stages}

The development of a large Middle Pleistocene ice cap with an average ELA of only $1256 \mathrm{~m}$ over the mountains bordering the eastern Adriatic has important implications for cold stage climates in this region. In order to build such a large ice sheet over a relatively low-altitude mountain such as Orjen climate must have been not just cold, but also humid. Table 4 illustrates the range of climate combinations that could have sustained the Orjen ice cap. Under precipitation values similar to today in the high mountain areas (5000-6000 mm), mean annual temperatures would need to be around $5-6{ }^{\circ} \mathrm{C}$ lower to form glaciers with ELAs similar to those of the Pleistocene. However, even a mean annual temperature depression of $12-13{ }^{\circ} \mathrm{C}$ would still have required over $1000 \mathrm{~mm}$ of annual snow accumulation (water equivalent) to balance ablation.

Hughes et al. (2007) have argued that the largest phase of glaciation in Greece (Skamnellian Stage, MIS 12), was characterised by the coldest summer temperatures of the last 423,000 years with summer temperatures c. $1{ }^{\circ} \mathrm{C}$ cooler than present. They also argued that this severe cooling allowed for the largest glacier expansion, even though later Pleistocene cold stages were likely to have been wetter. The argument for a much colder and drier MIS 12 
over the northern Mediterranean region, compared with later cold stages, is supported by pollen evidence from Greece (Tzedakis et al., 2003) and also by thick loess accumulations dating to this interval (430-480 ka) in the Pannonian basin (Marković et al., 2009). If the Orjen ice cap did form under drier conditions than today, which seems highly likely given the magnitude of modern precipitation, then, as noted above, the summer temperature depression compared with today must have been at least $6{ }^{\circ} \mathrm{C}$ cooler. The question remains: exactly how much cooler than today was the climate during MIS 12? Table 4 illustrates that the greater the temperature depression the lower the melt, and equally, the lower snow accumulation in order for a glacier to maintain equilibrium mass balance.

For Greece, Hughes et al. (2007) did not reconstruct the depression of mean annual temperatures for the largest phase of Middle Pleistocene glaciation, only summer temperatures. However, for the last cold stage in Greece periglacial evidence has been used to reconstruct mean annual temperatures that were $8-9{ }^{\circ} \mathrm{C}$ cooler than present (Hughes et al., 2003) - an estimate that is supported by independent evidence from other records (e.g. Peyron et al., 1998). If we use this depression for all the cold stage glaciers on Orjen, then this would have been associated with annual melt values that are $50-85 \%$ of the modern precipitation average at Crkvice (Tables 1 and 4). In the extreme scenario where temperatures are $15{ }^{\circ} \mathrm{C}$ cooler than present, then in all cold stages melt would have been $<500 \mathrm{~mm}$ at the ELA of the former glaciers. Obtaining the precise combination of temperature and melt that best describes the situation on the Pleistocene glaciers on Orjen is difficult without independent constraints on palaeotemperatures in the Orjen area. Nevertheless, it is clear from Table 4 that even under mean annual temperature depressions as great as $12-13^{\circ} \mathrm{C}$, snow accumulation totalling $>1000 \mathrm{~mm}$ would have been required to balance melting at the former glacier ELAs. Temperature depressions of this magnitude have not been reported from Europe for the Pleistocene cold stages, meaning that at least $1000 \mathrm{~mm}$ of precipitation supply must have been sustained on Orjen to support the glaciations. Whilst this is a mere $20 \%$ of the modern precipitation on Orjen, it is still a relatively 'high' value and is similar to the winter balance ( $1050 \mathrm{~mm}$ w.e.) on the Marmolada glacier on Mount Marmolada (3343 $\mathrm{m}, 46^{\circ} 26^{\prime} \mathrm{N}, 11^{\circ} 52^{\prime} \mathrm{E}$ ) in the Italian Dolomites (Kasser, 1973; Ohmura et al., 1992).

A climatic scenario whereby a Middle Pleistocene cold stage such as MIS 12 was very cold yet with ample moisture supply is best considered after examining the current climatic situation over the Adriatic and the western Balkans. The modern climate of the western Balkans is affected by cyclogenesis over the northern Mediterranean Sea (Llasat, 2009), which provides the dominant source of precipitation - especially during winter months. The main source areas for cyclogenesis include the Gulf of Genoa and the Adriatic Sea (Horvath et al., 2008). This phenomenon is closely related to vortices formed in the lee of the European Alps and modelling by Tafferner (1994) found that cyclogenesis would not occur over the Adriatic without the presence of this mountain range. Furthermore, Adriatic cyclones are intensified by orographically-induced pressure gradients caused by the Dinaric Alps, without which low pressure systems would quickly spread over the entire Balkan peninsula and weaken (Brzović and Jurčec, 1997).

During Pleistocene cold stages, the European landmass would have been much colder than at present - especially over the ice sheets of the Alps and the British Isles and Scandinavia. Major temperature contrasts between the European landmass and the Mediterranean Sea are likely to have sustained lee-side vortices to the south of the Alps, in the Gulf of Genoa and Adriatic Sea, in much the same way as is observed today. Whilst the Adriatic Sea would have been much reduced in size during the Pleistocene cold stages, especially in the north, sea would have been present south of a line between Ancona and Zadar (Correggiari et al., 1996) and would have been about $300 \mathrm{~km}$ wide reaching depths $>800 \mathrm{~m}$. However, a colder sea combined with colder air temperatures would have resulted in lower evaporation and a reduction in atmospheric moisture. Thus, the lee-side vortices would have generated weaker moisture-bearing depressions than today. Nevertheless, these weak moisture-bearing depressions would have tracked across the eastern Adriatic coastal mountains producing significant precipitation. The resultant large ice caps on the Dinaric Alps, such as on Orjen, Durmitor and many other massifs, would have acted as a barrier to the penetration of these depressions further inland resulting in a markedly drier Balkan interior. This may partly explain the deposition of thick accumulations of loess in the Pannonian basin (Marković et al., 2009). The northernmost Adriatic region is also likely to have been much drier than the south during cold stages and thick accumulations of loess formed in the Po basin during the Middle Pleistocene (Cremaschi, 1990a,b). This loess basin is unlikely to have been the source of moisture for depressions formed in the lee of the Alps. This is more likely to have been sourced from the present positions of the central and southern Adriatic which would have still been a significant water body during the Pleistocene cold stages.

Why were the post-MIS 12 glaciations smaller? This must be explained by warmer summer temperatures or drier conditions. Given the evidence from numerous records of cold and severely dry conditions during MIS 12 (Tzedakis et al., 2003; Marković et al., 2009), it is unlikely that later cold stages were drier. Instead of producing larger glaciers, wetter conditions during later Pleistocene cold stages such as MIS 6 and MIS 2 would have been offset by warmer summer temperatures. Indeed, a more temperate climate with warmer and wetter conditions during cold stages over the past $400 \mathrm{ka}$ explains the survival of temperate tree populations in the mountains of the Balkans (Tzedakis, 1993), although the western uplands would have always been much wetter than in the east (Tzedakis et al., 2004).

The last glacier on Orjen formed before $9.6 \pm 0.8 \mathrm{ka}$, probably during the Younger Dryas. This concurs with the findings of Asioli et al. (2001) in the central Adriatic, where a strong cold oscillation in sea surface temperatures occurred during the Younger Dryas, suggesting that the Mediterranean responded synchronously with changes in the North Atlantic. The Younger Dryas ELA on Orjen was very close to the mean ELA of earlier glaciers of the last cold stage. However, as noted earlier, this probably reflects the importance of local topoclimatic controls on the formation of this last single glacier. Some indication of the conditions required to support this glacier can be seen in Table 4 in the data for the glaciers of MIS 5d-2, which were similar to the Younger Dryas glacier. It is clear that even under mean annual temperature depressions of as much as $10{ }^{\circ} \mathrm{C}$, annual melt would have been $>2000 \mathrm{~mm}$, and for lower temperature depressions, much more. Whilst a large proportion of the snow accumulation necessary to balance such melting could have come from local inputs such as windblown and avalanching snow, precipitation was probably well in excess of $1000 \mathrm{~mm}$ during the Younger Dryas on Orjen and possibly several times that value, depending on the actual depression of temperatures at this time compared with today. This contradicts other interpretations of climate at this time based on palynological records from the region. Several studies investigating sediment cores from the Adriatic have shown that the Younger Dryas was characterised by high frequencies of herb pollen such as Artemisia and Chenopodiaceae. Rossignol-Strick (1995) and Favaretto et al. (2008) argued that elevated levels of Chenopodiaceae in cores from the central Adriatic indicate very dry conditions in the neighbouring lands, although the exact source of the pollen is not 
clear. The evidence from glaciers on Orjen at this time questions the validity of palaeoclimatic interpretations for the Younger Dryas in this region based on pollen data from marine cores - or, at least, indicates that the mountains were humid if not the lowlands.

\section{Conclusions}

Mount Orjen (1894 $\mathrm{m}$ ) on the coast of Montenegro is extensively glaciated and was covered by ice caps on at least two occasions during the Middle Pleistocene. U-series dating of secondary carbonates found within moraines indicates that these major glaciations occurred during MIS 12 (c. 480-430 ka) and MIS 6 (c. 190-130 ka). The largest ice cap covered an area of c. $165 \mathrm{~km}^{2}$ and reached a maximum ice thickness of c. $450 \mathrm{~m}$, reaching down to $500 \mathrm{~m}$ above modern sea level in some areas. In common with the glacial record from northern Greece, during the last cold stage of the Late Pleistocene (MIS 5d-2; 110.0-11.7 ka), glaciers were much smaller and were restricted to the highest valley areas. There is evidence that the last phase of glaciation occurred during the Younger Dryas - which is consistent with findings elsewhere in Montenegro and parts of northern Greece. All phases of glaciation would have required large amounts of snow accumulation. Mean annual temperatures $12-13{ }^{\circ} \mathrm{C}$ lower than today would still require $>1000 \mathrm{~mm}$ of snow accumulation (water equivalent) to balance ablation, suggesting sustained moisture supply during Pleistocene cold stages. Given that it is very unlikely that mean annual temperature depressions were greater than this at any time during the Pleistocene, it is clear that this area of the eastern Adriatic was relatively moist during cold stage glacial maxima. Major temperature contrasts between the European landmass and the Mediterranean Sea during the Pleistocene cold stages are likely to have sustained lee-side vortices to the south of the Alps, in the Gulf of Genoa and Adriatic Sea, generating moisture-bearing depressions which tracked across the eastern Adriatic coastal mountains - in much the same way as they do today. However, these cold stage depressions are likely to have been weaker and large ice caps on the Dinaric Alps are likely to have blocked their penetration inland, reducing moisture supply to the Balkan interior and the Pannonian basin resulting in a much drier environment favouring the deposition of thick sequences of loess. This process would have been especially pronounced during the Middle Pleistocene cold stages.

\section{Acknowledgements}

This research was supported by a Peter Fleming Award from the Royal Geographical Society (with IBG). The U-series dating was supported by the UK Natural Environment Research Council (IP/878/1105). We would like to thank Zoran Kljajić of the Institute of Marine Biology, Kotor, for help in the field and Pavle Cikovac for very useful information on the Orjen area. All of the figures were expertly drafted by Graham Bowden in the Cartographic Unit in the School of Environment and Development at the University of Manchester. We also thank the two anonymous reviewers for their helpful comments.

\section{References}

Akçar, N., Yavuz, V., Ivy-Ochs, S., Kubik, P.W., Vardar, M., Schlüchter, C., 2007. Paleoglacial records from Kavron Valley, NE Turkey: field and cosmogenic exposure dating evidence. Quaternary International 164-165, 170-183.

Akçar, N., Yavuz, V., Ivy-Ochs, S., Kubik, P.W., Vardar, M., Schlüchter, C., 2008. A case for a down wasting mountain glacier during Termination I, Verçenik Valley, NE Turkey. Journal of Quaternary Science 23, 273-285.

van Andel, T.H., Shackleton, J.C., 1982. Late Paleolithic and Mesolithic coastlines of Greece and the Aegean. Journal of Field Archaeology 9, 445-454.
Asioli, A., Trincardi, F., Lowe, J.J., Ariztegui, D., Langone, L., Oldfield, F., 2001. Submillennial scale climatic oscillations in the central Adriatic during the Lateglacial: palaeoceanographic implications. Quaternary Science Reviews 20, 1201-1221.

Bertić, I. (Ed.), 1987. Veliki geografski Atlas Jugoslavije. Sveučilišna naklada Liber, Zagreb.

Birkeland, P.W., 1999. Soils and Geomorphology, third ed. Oxford University Press, New York.

Boenzi, F., Palmentola, G., 1997. Glacial features and snow-line trend during the last glacial age in the southern Apennines (Italy) and on Albanian and Greek mountains. Zeitschrift für Geomorphologie 41, 21-29.

Bortoluzzi, G., Del Bianco, F., D’Oriano, F., Giglio, F., Borgia, T.T.M., Santi, D., Bulatović, A., Dević, N., Radojević, D., Matović, M., Sretenović, A., Diaconov, A., Tola, M., May 2009. Report on the Morphobathymetric, Oceanographic, Geological and Geophysical Investigations During Cruise MNG01_09 (19-27 April 2009, R/V URANIA), ISMAR-CHR Interim Technical Cruise Report. Bologna, $27 \mathrm{pp}$.

Bottema, S., 1995. The Younger Dryas in the eastern Mediterranean. Quaternary Science Reviews 14, 883-891.

Braithwaite, R.J., 2008. Temperature and precipitation climate at the equilibriumline altitude of glaciers expressed by the degree-day factor for melting snow. Journal of Glaciology 54, 437-444.

Braithwaite, R.J., Raper, S.C.B., Chutko, K., 2006. Accumulation at the equilibrium line altitude of glaciers inferred from a degree-day model and tested against field observations. Annals of Glaciology 43, 329-334.

Brugger, K.A., 2006. Late Pleistocene climate inferred from the reconstruction of the Taylor River glacier complex, southern Sawatch Range, Colorado. Geomorphology $75,318-329$.

Brzović, N., Jurčec, V., 1997. Numerical simulation of the Adriatic cyclone development. Geofizika 14, 29-46.

Burgess, D.O., Sharp, M.J., 2004. Recent changes in Areal extent of the Devon ice cap, Nunavut, Canada. Arctic, Antarctic and Alpine Research 36, 261-271.

van Calsteren, P., Schwieters, J.B., 1995. Performance of a thermal ionisation mass spectrometer with a deceleration lens system and post-deceleration detector selection. International Journal of Mass Spectrometry and Ion Processes 146/147, 119-129.

Correggiari, A., Roveri, M., Trincardi, F., 1996. Late Pleistocene and Holocene evolution of the north Adriatic sea. Quaternario 9, 697-704.

Cowton, T., Hughes, P.D., Gibbard, P.L., 2009. Palaeoglaciation of Parque Natural Lago de Sanabria, northwest Spain. Geomorphology 108, 282-291.

Cremaschi, M., 1990a. The loess in northern and central Italy: a loess basin between the Alps and the Mediterranean regions. In: Cremaschi, M. (Ed.), The Loess in Northern and Central Italy: a Loess Basin between the Alps and the Mediterranean Region. Quaderni di geodinamica Alpina e Quaternaria, vol. 1, pp. 15-19. Milano.

Cremaschi, M., 1990b. Stratigraphy and palaeoenvironmental significance of the loess deposits on Susak Island (Dalmatian Archipelago). Quaternary International 5, 97-106.

Cvijić, J., 1900. L'époque glaciaire dans la péninsule des Balkans. Annales de Géographie 9, 359-372.

Cvijić, J., 1917. L'époque glaciaire dans la péninsule des Balkanique. Annales de Géographie 26, 189-218.

Djurović, P., 2009. Reconstruction of the Pleistocene glaciers of Mt. Durmitor in Montenegro. Acta Geographica Slovenica 49-2, 263-289.

Edwards, R.L., Chen, H., Wasserburg, G.J., $1987 .{ }^{238} \mathrm{U}-{ }^{234} \mathrm{U}-{ }^{230} \mathrm{Th}-{ }^{232} \mathrm{Th}$ systematics and the precise measurement of time over the past 500,000 years. Earth and Planetary Science Letters 81, 175-192.

Ehlers, J., Gibbard, P.L., 2008. Extent and chronology of Quaternary glaciation. Episodes 31, 211-218.

Favaretto, S., Asioli, A., Miola, A., Piva, A., 2008. Preboreal climatic oscillations recorded by pollen and foraminifera in the southern Adriatic Sea. Quaternary International 190, 89-102.

Fernández-Mosquera, D., Marti, K., Vidal Romani, J.R., Weigel, A., 2000. Late Pleistocene deglaciation chronology in the NW of the Iberian Peninsula using cosmic-ray produced $21 \mathrm{NE}$ in quartz. Nuclear Instruments and Methods in Physics Research B172, 832-837.

Giraudi, et al. The Middle and late Pleistocene glaciations in the Campo Felice basin (Central Apennines - Italy). Quaternary Research, in press.

Golledge, N., Hubbard, A., Bradwell, T., 2009. Influence of seasonality on glacier mass balance, and implications for palaeoclimate reconstructions. Climate Dynamics. doi:10.1007/s00382-009-0616-6.

Granger, D.E., Spagnolo, M., Federici, P., Pappalardo, M., Ribolini, A., Cyr, A.J., 2006. Last Glacial Maximum dated by means of ${ }^{10} \mathrm{Be}$ in the Maritime Alps (Italy). Eos Transactions, American Geophysical Union 87 Fall Meeting Supplement, Abstract H53B-0634.

Groupe Spéléologique Muséum National d'Histoire Naturelle, Paris, 2003. Rapport de l'expédition le chemins d'Orjen 2003 organisée par Groupe Spéléologique Minos, Paris. Expédition du 30 juillet au 20 août 2003 au Monténégro (Crna Gora), $68 \mathrm{pp}$.

Grund, A., 1910. Beiträge zur Geomorphologie des Dinarischen Gebirges. Geographische Abhandlungen 7 (H.3), 121-125.

Harden, J.W., 1982. A quantitative index of soil development from field descriptions: examples from a chronosequence in central California. Geoderma 28, 1-28.

Hellstrom, J., 2006. U-Th dating of speleothems with high initial ${ }^{230}$ Th using stratigraphical constraint. Quaternary Geochronology 1, 289-295. 
Hewitt, G.M., 2000. The genetic legacy of the Quaternary ice ages. Nature 405, 907-913.

Horvath, K., Lin, Y.-L., Ivančan-Picek, B., 2008. Classification of cyclone tracks over the Apennines and the Adriatic sea. Monthly Weather Review 136, 2210-2227.

Hughes, P.D., 2008. Response of a Montenegro glacier to extreme summer heatwaves in 2003 and 2007. Geografiska Annaler 90A, 259-267.

Hughes, P.D., 2009a. Loch Lomond Stadial (Younger Dryas) glaciers and climate in Wales. Geological Journal 44, 375-391.

Hughes, P.D., 2009b. Twenty-first century glaciers in the Prokletije mountains, Albania. Arctic, Antarctic and Alpine Research 41, 455-459.

Hughes, P.D., 2010. Little Ice age glaciers in the Balkans: low altitude glaciation enabled by cooler temperatures and local topoclimatic controls. Earth Surface Processes and Landforms 35, 229-241.

Hughes, P.D., Gibbard, P.L., Woodward, J.C., 2003. Relict rock glaciers as indicators of Mediterranean palaeoclimate during the Last Glacial Maximum (Late Würmian) of northwest Greece. Journal of Quaternary Science 18, 431-440.

Hughes, P.D., Gibbard, P.L., Woodward, J.C., 2005. A Formal stratigraphical approach for Quaternary glacial records in mountain regions. Episodes 28, 85-92.

Hughes, P.D., Woodward, J.C., Gibbard, P.L., 2006a. Glacial history of the Mediterranean mountains. Progress in Physical Geography 30, 334-364.

Hughes, P.D., Woodward, J.C., Gibbard, P.L., 2006b. Late Pleistocene glaciers and climate in the Mediterranean region. Global and Planetary Change 46, 83-98.

Hughes, P.D., Woodward, J.C., Gibbard, P.L., Macklin, M.G., Gilmour, M.A., Smith, G.R., 2006c. The glacial history of the Pindus Mountains, Greece. Journal of Geology $114,413-434$.

Hughes, P.D., Woodward, J.C., Gibbard, P.L., 2006d. The last glaciers of Greece. Zeitschrift für Geomorphologie 50, 37-61.

Hughes, P.D., Woodward, J.C., Gibbard, P.L., 2007. Middle Pleistocene cold stage climates in the Mediterranean: new evidence from the glacial record. Earth and Planetary Science Letters 253, 50-56.

Hughes, P.D., Braithwaite, R.J., 2008. Application of a degree-day model to reconstruct Pleistocene glacial climates. Quaternary Research 69, 110-116.

Hughes, P.D., Woodward, J.C., 2008. Timing of glaciation in the Mediterranean mountains during the last cold stage. Journal of Quaternary Science 23 575-588

Hughes, P.D., Woodward, J.C., 2009. Chapter 12: glacial and periglacial environments. In: Woodward, J.C. (Ed.), The Physical Geography of the Mediterranean. Oxford University Press, Oxford, pp. 353-383.

Karkanas, P., 2001. Site formation processes in Theopetra cave: a record of climatic change during the Late Pleistocene and early Holocene in Thessaly, Greece. Geoarchaeology: An International Journal 16, 373-399.

Kasser, P., 1973. Fluctuations of Glaciers 1965-1970. International Association of Hydrological Sciences/UNESCO, Paris, 357 pp.

Kirigin, B., 1967. Klimatske karakteristike Sjevernog Velebita. In: Zbornik radova X kongresa klimatologa Jugoslavije, Kopaonik, Beograd, pp. 189-206.

Kotarba, A., Hercman, H., Dramis, F., 2001. On the age of Campo Imperatore glaciations, Gran Sasso massif, central Italy. Geografia Fisica e Dinamica Quaternaria 24, 65-69.

Kuhlemann, J., Rohling, E.J., Krumrei, I., Kubik, P., Ivy-Ochs, S., Kucera, M., 2008. Regional synthesis of Mediterranean atmospheric circulation during the Last Glacial Maximum. Science 321, 1338-1340.

Kuhlemann, J., Milivojević, M., Krumrei, I., Kubik, P.W., 2009. Last glaciation of the Šara range (Balkan peninsula): Increasing dryness from the LGM to the Holocene. Austrian Journal of Earth Sciences 102, 146-158.

Lawson, I.T., Frogley, M., Bryant, C., Preece, R., Tzedakis, P.C., 2004. The Lateglacial and Holocene environmental history of the Ioannina basin, north-west Greece. Quaternary Science Reviews 23, 1599-1625.

Leonard, E.M., 1984. Late Pleistocene equilibrium-line altitudes and modern snow accumulation patterns, San Juan Mountains, Colorado, U.S.A. Arctic and Alpine Research 16, 65-76.

Lewin, J., Woodward, J.C., 2009. Karst geomorphology and environmental change. In: Woodward, J.C. (Ed.), The Physical Geography of the Mediterranean. Oxford University Press, Oxford, pp. 287-317.

Lewis, C.J., McDonald, E.V., Sancho, C., Luis Peña, J., Rhodes, E.J., 2009. Climatic implications of correlated Upper Pleistocene glacial and fluvial deposits on the Cinca and Gállego Rivers (NE Spain) based on OSL dating and soil stratigraphy. Global and Planetary Change 67, 141-152.

Liedtke, H., 1962. Eisrand und Karstpoljen am Westrand Lukavica-Hochfläche. Erdkunde 16, 289-298.

Llasat, M.-C., 2009. Storms and floods. In: Woodward, J.C. (Ed.), The Physical Geography of the Mediterranean. Oxford University Press, Oxford, pp. 513-540.

Magaš, D., 2002. Natural-geographic characteristics of the Boka Kotorska area as the basis of development. Geoadria 7/1, 51-81.

Marjanac, L., Marjanac, T., 2004. Glacial history of the Croatian Adriatic and coastal Dinarides. In: Ehlers, J., Gibbard, P.L. (Eds.), Quaternary Glaciations - Extent and Chronology. Part I: Europe. Elsevier, Amsterdam, pp. 19-26.

Marković, S.B., Hambach, U., Catto, N., Jovanović, M., Buggle, B., Machlett, B., Zöller, L., Glaser, B., Frechen, M., 2009. Middle and late Pleistocene loess sequences at Batajnica, Vojvodina, Serbia. Quaternary International 198, 255-266.

Marović, M., Marković, M., 1972. Glacial morphology of the Durmitor Mt. wider area (in Serbian). Geoloski anali Balkanskog poluostrva 37, 37-48.
Meier, M.F., Post, A.S., 1962. Recent variations in mass net budgets of glaciers in western North America. International Association of Hydrological Sciences Publication 58, 63-77.

Menković, L., Marković, M., Ćupković, T., Pavlović, R., Trivić, B., Banjać, N., 2004 Glacial morphology of Serbia Yugoslavia, with comments on the Pleistocene glaciation of Montenegro, Macedonia and Albania. In: Ehlers, J., Gibbard, P.L. (Eds.), Quaternary Glaciations-extent and Chronology. Part I: Europe. Elsevier, Amsterdam, pp. 379-384.

Messerli, B., 1967. Die eiszeitliche und die gegenwartige Vertgletscherung im Mittelemeeraum. Geographica Helvetica 22, 105-228.

Mileta, M., 2005. Fog water collection in Croatia. Croatian Meteorological Journal 41, 624-626.

Milivojević, M., Menković, L., Ćalić, J., 2008. Pleistocene glacial relief of the central part of Mt. Prokletije (Albanian Alps). Quaternary International 190, 112-122.

Mîndrescu, M., Evans, I.S., Cox, N.J., 2010. Climatic implications of cirque distribution in the Romanian Carpathians: palaeowind directions during glacial periods. Journal of Quaternary Science. doi:10.1002/jqs.1363.

Nicod, J., 1968. Premières recherches de morphologie karstique dans le massif du Durmitor (Crna Gora: Montenegro). Meditérraneé 3, 187-216.

Ohmura, A., Kasser, P., Funk, M., 1992. Climate at the equilibrium line of glaciers Journal of Glaciology 38, 397-411.

Osmaston, H., 2002. Chapter 9. The nature, extents and climates of former Quaternary tropical glaciers, with reference to the East African Mountains. In: Kaser, G., Osmaston, H. (Eds.), Tropical Glaciers. Cambridge University Press, Cambridge, pp. 149-192.

Penck, A., 1900. Die Eiszeit auf der Balkanhalbinsel. Globus 78, 133-178.

Peyron, O., Guiot, J., Cheddadi, R., Tarasov, P., Reille, M., de Beaulieu, J.-L., Bottema, S. Andrieu, V., 1998. Climatic reconstruction in Europe for 18,000 yr B.P. from pollen data. Quaternary Research 49, 183-196.

Porter, S.C., 1975. Equilibrium-line altitudes of late Quaternary glaciers in the southern Alps, New Zealand. Quaternary Research 5, 27-47.

Rossignol-Strick, M., 1995. Sea-land correlation of pollen records in the eastern Mediterranean for the glacial-interglacial transition: biostratigraphy versus radiometric timescale. Quaternary Science Reviews 14, 893-915.

Sarıkaya, M.A., Zreda, M., Çiner, A., 2009. Glaciations and paleoclimate of Mount Erciyes, central Turkey, since the Last Glacial Maximum, inferred from ${ }^{36} \mathrm{Cl}$ dating and glacier modeling. Quaternary Science Reviews 23-24, 2326-2341.

Sarıkaya, M.A., Zreda, M., Çiner, A., Zweck, C., 2008. Cold and wet Last Glacial Maximum on Mount Sandıras, SW Turkey, inferred from cosmogenic dating and glacier modelling. Quaternary Science Reviews 27, 769-780.

Sawicki, L.von., 1911. Die eiszeitliche Vergletscherung des Orjen in Süddalmatien. Zeitscrift für Gletscherkunde 5, 339-355.

Schwarcz, H.P., 1989. Uranium series dating of Quaternary deposits. Quaternary International 1, 7-17.

Stepišnik, U., Ferk, M., Kodelja, B., Medenjak, G., Mihevc, A., Natek, K., Žebre, M., 2009. Glaciokarst of western Orjen. Cave and Karst Science 36, 21-28.

Tafferner, A., 1994. Life cycle of a mountain generated Adriatic cyclone. Annalen der Meterologie 30, 73-77.

Tisserant, J., 1974. Troisième campagne à l'Orjen (Yougoslavie - Monténégro 1976) Bulletin du Spéléo Club des Ardennes 5, 1-25.

Turner, S., van Calsteren, P., Vigier, N., Thomas, L., 2001. Determination of thorium and uranium isotope ratios in low-concentration geological materials using a fixed multi-collector MC-ICP-MS. Journal of Analytical Atomic Spectrometry $16,612-615$.

Tzedakis, P.C., 1993. Long-term tree populations in northwest Greece through multiple Quaternary climatic cycles. Nature 364, 437-440.

Tzedakis, P.C., 2005. Towards an understanding of the response of southern European vegetation to orbital and suborbital climate variability. Quaternary Science Reviews 24, 1585-1599.

Tzedakis, P.C., McManus, J.F., Hooghiemstra, H., Oppo, D.W., Wijmstra, T.A., 2003. Comparison of changes in vegetation in northeast Greece with records of climate variability on orbital and suborbital frequencies over the last 450,000 years. Earth and Planetary Science Letters 212, 197-212.

Tzedakis, P.C., Frogley, M.R., Lawson, I.T., Preece, R.C., Cacho, I., de Abreu, L., 2004. Ecological thresholds and patterns of millennial-scale climate variability: the response of vegetation in Greece during the last glacial period. Geology 32, 109-112.

Vidal-Romaní, J.R., Fernández-Mosquera, D., 2006. Glaciarismo Pleistoceno en el NW de la peninsula Ibérica (Galicia, España-Norte de Portugal). Enseñanza de las Ciencias de la Tierra 13, 270-277. http://www.raco.cat/index.php/ect/ article/view/89058/133836.

Vieira, G.T., 2007. Combined numerical and geomorphological reconstruction of the Serra da Estrela plateau icefield, Portugal. Geomorphology 97, 190-207.

Wilson, G.P., Reed, J.M., Lawson, I.T., Frogley, M.R., Preece, R.C., Tzedakis, P.C., 2008. Diatom response to the last Glacial-Interglacial transition in the Ioannina basin, northwest Greece: implications for Mediterranean palaeoclimate reconstruction. Quaternary Science Reviews 27, 428-440.

Woodward, J.C., Macklin, M.G., Smith, G.R., 2004. Pleistocene glaciation in the mountains of Greece. In: Ehlers, J., Gibbard, P.L. (Eds.), Quaternary Glaciations Extent and Chronology: Part 1. Elsevier, Amsterdam, pp. 155-173.

Woodward, J.C., Hamlin, R.H.B., Macklin, M.G., Hughes, P.D., Lewin, J., 2008. Glacial activity and catchment dynamics in northwest Greece: long-term rive behaviour and the slackwater sediment record for the last glacial to interglacial transition. Geomorphology 101, 44-67. 